\title{
PHYLOGENY AND CLASSIFICATION OF EUPELMIDAE, WITH A REVISION OF THE WORLD GENERA OF CALOSOTINAE AND METAPELMATINAE (HYMENOPTERA: CHALCIDOIDEA)
}

\author{
GARY A. P. GIBSON
}

Biosystematics Research Centre

Agriculture Canada Research Branch

K.W. Neatby Building

Ottawa, Ontario, Canada

K1A 0C6

MEMOIRS OF

THE ENTOMOLOGICAL SOCIETY OF CANADA - No. 149

A.B. Ewen, Editor

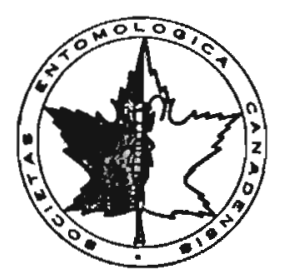

THE ENTOMOLOGICAL SOCIETY OF CANADA 1320 Carling Avenue Ottawa K1Z $7 \mathrm{~K} 9$ 1989

Second Class Mail Registration No. 8090 
The Memoirs are subject to the same standards and review requirements as are contributions to The Canadian Entomologist except that more editorial latitude is permitted. Instructions to authors are printed in the January issue of The Canadian Entomologist. 


\section{CONTENTS}

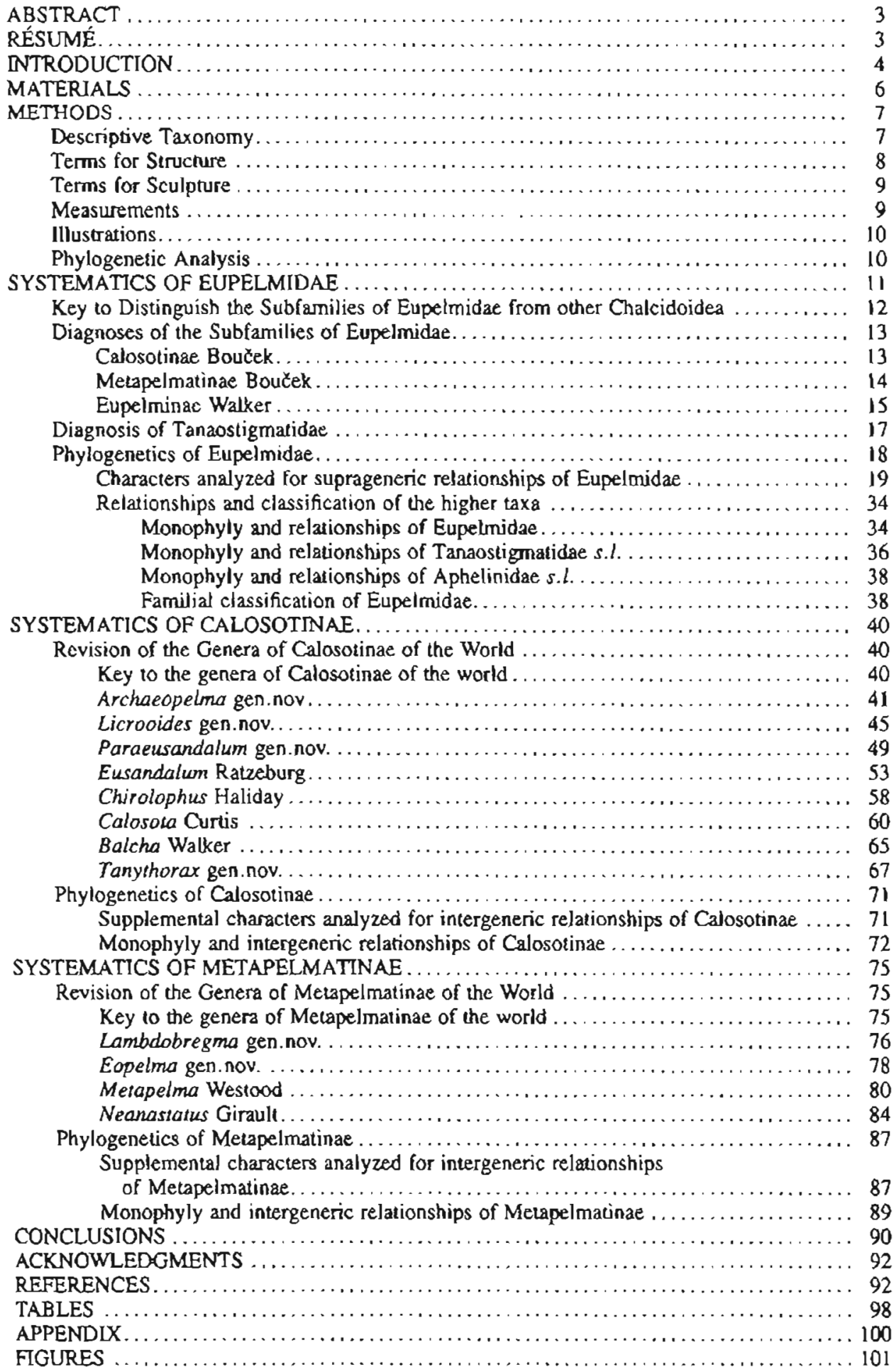





\title{
PHYLOGENY AND CLASSIFICATION OF EUPELMIDAE, WITH A REVISION OF THE WORLD GENERA OF CALOSOTINAE AND METAPELMATINAE (HYMENOPTERA: CHALCIDOLEA)
}

\author{
GARY A. P. GiBSON \\ Biosystematics Research Centre, Agriculture Canada Research Branch, K.W. Neatby Building, Ottawa, \\ Ontario, Canada KIA 0C6
}

\begin{abstract}
Mem. ent. Soc. Can. 148: 3-121 (1989)

Three subfamilies are classified in Eupelmidae: Calosotinae Boucek, Eupelminae Walker, and Metapelmatinae Boucek. Diagnoses of these three subfamilies and of Tanaostigmatidae are given, together with a key to distinguish members from each other and from other Chalcidoidea. Genera of Calosotinae and Metapelmatinae are revised for the world, with a key tn genera given for both subfamilies. For each genus the following is provided: synonymy, description of structural features of males and females, notes on distribution and hosts, available keys to species listed by biogeographic region, and a catalog of species. New generic combinations are made in the catalogs of species based on examination of type specimens of the species. Eight genera are included in Calosotinae [type species in brackets]: Archaeopelma gen.nov. [A. tropeotergum sp.nov.], Licrooides gen.nov. [L. umbilicatus sp.nov.], Paraeusandalum gen.nov. [P. chilense sp.nov.], Eusandalum Ratzeburg, Chirolophus Haliday, Calosota Curtis, Balcha Walker, and Tanythorax gen.nov. [T. spinosus sp.nov.]. Four genera are included in Metapelmatinae: Metapelma Westwood, Neanastatus Girault, Eopelma gen.nov. [E. mystax sp.nov.], and Lambdobregma gen.nov. [L. schwarzii (Ashmead) comb.nov.]. The following are proposed as new synonymies: Notosandalum De Santis and Exosandalum Boucek = Eusandalum Ratzeburg, and Metacalosoter Masi = Calosota Curtis. Eighteen structural features of adults of the three eupelmid subfamilies, and of other Chalcidoidea including Tanaostigmatidae, Encyrtidae, Aphelinidae, and Pteromalidae, are studied to delimit character states and determine their distribution among the higher taxa. Twenty-two additional features of adults of Calosotinae and Metapelmatinae are studied for supplemental evidence of relationships among the genera in these two subfamilies. Observed character-state distributions are used to postulate character polarity and homoplastic states, and hypotheses of monophyly and relationships among taxa are based on proposed synapomorphic states. Aphelinidae sensu lato (including the subfamily Eriaporinae) are indicated as either a paraphyletic or polyphyletic taxon if the Eriaporinae are included but the Signiphoridae are excluded. Tanaostigmatidae sensu lato (including the genus Cynipencyrtus Ishii) are indicated as the sister group of Encyrtidae based on a relatively long mesoscutal process for the muscle $\mathrm{pl}_{2}-\mathrm{t}_{2} \mathrm{c}$, and structure of the articulation between the mesoscutum and scutellar-axillar complex. The genus Cynipencyrtus Ishii is indicated to be most closely related to Encyrtidae based on common possession of transverse axillae and mesotibial apical pegs. Possible relationships among Calosotinae, Metapelmatinae, and Eupelminae, and among these and Tanaostigmatidae + Encyrtidae remain unresolved. There are no derived character states unique to either Eupelmidae, or Eupelmidae + (Tanaostigmatidae + Encyrtidae), so that these taxa and relationships are not definitively supported as monophyletic. Eupelmidae may represent a grade-level taxon with membership determined by similar suites of apomorphic states that function to enhance jumping ability. Cladograms are used to illustrate alternate hypotheses of characterstate evolution and relationships among the genera of Calosotinae and Metapelmatinae. Distribution of character states for the higher taxa and for each genus of Calosotinae and Metapelmatinae is summarized in two tables. Scanning electron photomicrographs are used to illustrate structural features.
\end{abstract}

\section{Résumé}

Trois sous-familles sont classées parmi les Eupelmidae: les Calosotinae Bouček, les Eupelminae Walker et les Metapelmatinae Boucek. Une analyse de ces trois sousfamilles et des Tanaostigmatidae est présentée, ainsi qu'une clé permettant de distinguer 
les membres entre eux et de les différencier des autres Chalcidoidea. Les genres des Calosotinae et des Metapelmatinae sont révisés à l'échelle mondiale, et une clé d'identification des genres donnés pour les deux sous-familles est présentée. Pour chaque genre, on foumit les renseignements suivants: les synonymes, la description des caractères structuraux des mâles et des femelles, des notes sur la distribution et les hôtes, les clés disponibles pour l'identification des espèces énumérées par région biogéographique et un catalogue d'espèces. Les nouvelles combinaisons de genres qui figurent dans la catalogue sont basécs sur l'examen de spécimens type de l'espèce. Huit genres sont inclus dans les Calosotinae [espèce type entre crochets]: Archaeopelma gen.nov. [A. tropeotergum sp.nov.], Licrooides gen.nov. [L. umbilicatus sp.nov.], Paraeusandalum gen.nov. [P. chilense sp.nov.], Eusandalum Ratzeburg, Chirolophus Haliday, Calosota Curtis, Balchu Walker et Tanythorax gen.nov. [T. spinosus sp.nov.]. Quatre genres sont inclus dans les Metapelmatinae: Metapelma Westwood, Neanastatus Girault, Eupelma gen.nov. [E. mystax sp.nov.], et Lambdobregma gen.nov. [L. schwarzii (Ashmead) comb.nov.]. Les nouveaux synonymes suivants sont proposés: Notosandalum De Santis et Exosandalum Bouček = Eusandalum Ratzeburg, et Metacalosoter Masi = Calosota Curtis. Dix-huit caractères structuraux des adultes des trois sous-familles d'eupelmidés et d'autres Chalcidoidea, y compris les Tanaostigmatidae, les Encyrtidae, les Aphelinidae et les Pteromalidae sont étudiés afin de délimiter les caractéristiques et d'établir leur distribution parmi les taxons supérieurs. Vingt-deux autres caractères additionnels des adultes des Calosotinae et des Metapelmatinae sont étudiés afin d'obtenir d'autres preuves de relations entre les genres dans ces deux sous-familles. La distribution des caractéristiques qui a été établie sert à postuler la polarité de transformation des caractères et les caractères homoplastiques, tandis que les hypothèses de monophylétisme et de relations entre les taxons sont basées sur les synamorphies proposées. Les Aphelinidae au sens large (y compris la sousfamille des Eriaporinae) forme un taxon paraphylétique ou polyphylétique si les Eriaporinae en font partie et qu'en sont exclus les Signiphoridae. Les Tanaostigmatidae au sens large (y compris le genre Cynipencyrtus Ishii) forment un taxon frère des Encyrtidae en raison de la présence d'une apophyse mésoscutale relativement longue pour le muscle $\mathrm{pl}_{2}-t_{2} \mathrm{c}$, et de la structure de l'articulation entre le mésoscutum et le complex scutellaire-axillaire. Le genre Cynipencyrtus Ishii est le plus étroitement relié aux Encyrtidae en raison de la possession commune d'axilles transverses et d'organes sensoriels en forme de cheville à l'apex du mésotibia. Les relations possibles entre les Calosotinae, les Metapelmatinae et les Eupelminae, et entre ces derniers et les Tanaostigmatidae + Encyrtidae ne sont pas encore élucidées. Aucune caractéristique dérivée n'est unique aux eupelmidae ni aux Eupelmidae + (Tanaostigmatidae + Encyrtidae), aussi n'y a-t-il pas de preuve définitive à l'appui du monophylétisme de ces taxons et de ces relations. Les Eupelmidae peuvent représenter un taxon informel dont les membres présentent des séries semblables de caractères dérivés favorisant une meilleure aptitude au saut. Des cladogrammes sont utilisés pour illustrer les autres hypothèses sur l'évolution des caractéristiques et les relations entre les genres des Calosotinae et des Metapelmatinae. La distribution des caractéristiques pour les taxons supérieurs et pour chaque genre des Calosotinae et des Metapelmatinae est résumée dans deux tableaux. Des photographies prises au microscope électronique à balayage servent à illustrer les caractères structuraux.

\section{INTRODUCTION}

Walker (1833: 368) first used the family name Eupelmidae, though he initially (Walker 1837) classified some genera now assigned to Eupelmidae in the family Cleonymidae. Walker (1846b: 114) later listed seven genera as constituting the family Eupelmidae without giving reasons or characters for his taxon. He also listed another five genera, now assigned to the Cleonyminae (Pteromalidae), as "nearly allied" to Eupelmidae. Walker (1872: 81) further stated that "there does not seem to be any near affinity between the Eupelmidae and the Encyrtidae, notwithstanding their mutual resemblance in structure of the middle legs". 
Foerster (1856) first diagnosed and distinguished Eupelmidae from Encyrtidae, but Ashmead $(1899,1900 a, 1904 a)$ included eupelmids as a subfamily of Encyrtidae along with Encyrtinae and Signiphorinae. Ashmead defined Encyrtidae on the basis of a large and non-impressed mesopleuron, saltatorial mesotibial spur, and a large triangular mesepisternum [ = prepectus]. He further distinguished Eupelminae from the other two subfamilies on the basis of a "usually long" marginal vein and a particular structure of the mesoscutum (Ashmead 1899: 248, 1900a: 324, 1904a: 286). Ashmead (1904a) also recognized two tribes in Eupelminae, Eupelmini and Tanaostigmini, the latter tribe distinguished on the basis of a convex mesonotum and form of the notauli.

Other than the ranking of the respective taxa, little changed in the classification of eupelmids until Bouček (1958) organized the genera into Eupelminae s.s. and his new subfamily Calosotinae. He distinguished Calosotinae primarily on the structure of the mesoscutum, but also noted that unlike the Eupelminae members were always fully winged and there was little sexual dimorphism in thoracic structure. Boucek (1988) further restricted the concept of Eupelminae by establishing the new subfamily Metapelmatinae for Metapelma Westwood and Neanastatus Girault. Though he distinguished Metapelmatinae from Eupelminae and Calosotinae, he did not postulate on their relationships except for stating that Calosotinae were the most plesiomorphic of the three subfamilies. Boucek (1958) suggested that Calosotinae were related to Pteromalidae through several genera of Cleonyminae, in particular Oodera Westwood, and (1988: 540) stated that "it seems beyond doubt that Eupelmidae developed from some primitive ancestors of Pteromalidae, as comparison with the pteromalid subfamily Cleonyminae suggests".

The concepts of Graham $(1969 b)$ were similar to those of Boucek $(1958,1988)$. Graham (1969b: 36) stated that the genus Oodera forms "a link between Eupelmidae and Cleonyminae (Pteromalidae), having some characters peculiar to both", and concluded that "these twn groups must I think have originated from a common stock". However, Graham (1969b) "doubted" the classification of Oodera in Cleonyminae, and in his key to families of Chalcidoidea keyed the genus out in Eupelmidae. He also suggested that uniting the Eupelmidae with Pteromalidae might establish a more mature classification of Chalcidoidea by reducing the number of recognized families.

Riek's (1970) classification of eupelmids was quite different from those of Boucek (1958) and Graham (1969b). Riek included eupelmids, tanaostigmatids (Tanaostigmodinae sensu Riek), signiphorids (Thysaninae sensu Riek), aphelinids, and encyrtids, as five separate subfamilies of the family Encyrtidae. His family concept was intended to encompass all chalcidoid species in which the middle leg is modified for jumping. Unlike Riek (1970), Burks (1979: 878) considered that "all eupelmids agree in possessing an array of characters that indicate that they and encyrtids diverged separately from the evolutionary stem of chalcidoids at a remote time in the development of the superfamily". Consequently, he recognized Eupelmidae as a family separate from Encyrtidae, and included Eupelminae, Calosotinae, and Tanaostigmatinae as subfamilies.

LaSalle (1987) was the first to assess monophyly of Encyrtidae and Eupelmidae and to examine relationships between the higher taxa using explicit cladistic methodology. $\mathrm{He}$ hypothesized that tanaostigmatids represent a monophyletic clade based on one putative autapomorphy (prepectus enlarged and distinctly swollen anteriorly), and treated them as a family level taxon. He also hypothesized that tanaostigmatids are more closely related to encyrtids than to eupelmids based on two proposed synapomorphies (sinuately convergent notauli and ovarian eggs of encyrtiform type), and that Eupelmidae + (Encyrtidae + Tanaostigmatidae) form a monophyletic assemblage based on two other putative synapomorphies (convex mesopleuron and middle leg with a combination of large tibial spur and peg-like spines on the ventral surface of at least the basitarsus). However, because he knew of no autapomorphies for Eupelmidae he suggested that Eupelmidae probably is paraphyletic relative to Tanaostigmatidae and Encyrtidae. 
My paper has two major aims: to investigate the phylogenetics and classification of Eupelmidae, and to revise the world genera of Calosotinae and Metapelmatinae. I base familial and subfamilial classification of Eupelmidae primarily on external and internal characters of the mesosoma. Members of Calosotinae and Metapelmatinae are very diverse in most of these characters; therefore, it was necessary to revise the world genera to determine accurately character-state distribution prior to phylogenetic analyses of familiallevel relationships. Structure of the mesosoma is even more diverse in Eupelminae because of sexual dimorphism, but I previously described differences in the mesothoracic skeletomusculature of male and female eupelmines (Gibson 1986b).

\section{MATERIALS}

The list below details collections examined for this study, acronyms used for the collections, and curators who provided loans or access to collections in their care. The symbol " $t$ " indicates a collection that contains primary type material of Calosotinae or Metapelmatinae, whereas an asterisk $(*)$ indicates a collection that was examined. Thus, collections designated only by a " $t$ " were not examined, but the acronyms are used in the text to indicate location of type material.

\begin{tabular}{|c|c|}
\hline AEI $\left(t^{*}\right)$ & American Entomological Institute, Gainesville, FL, USA (H. Townes). \\
\hline AMUA (t) & Aligarh Muslim University, Aligarh, India. \\
\hline ANIC* $(t)$ & Australian National Insect Collection, Canberra City, Australia (I. Naumann). \\
\hline BMNH (t*) & British Museum (Natural History), London, England (Z. Boucek and J. Noyes). \\
\hline BPBM* & Bemice P. Bishop Museum, Honolulu, HI, USA (G. Nishida). \\
\hline $\operatorname{CAS}\left(\mathbf{t}^{*}\right)$ & $\begin{array}{l}\text { California Academy of Sciences, San Francisco, CA, USA (P. Amaud and W. } \\
\text { Pulawski). }\end{array}$ \\
\hline CDAS* & $\begin{array}{l}\text { California Department of Food and Agriculture, Sacramento, CA, USA (M. } \\
\text { Wasbauer). }\end{array}$ \\
\hline CMP* & Carnegie Museum, Pittsburgh, PA, USA (G. Ekis and G. Wallace). \\
\hline CNC (t*) & Canadian National Collection, Agriculture Canada, Ottawa, Ont., Canada. \\
\hline $\mathbf{C U}\left(\mathbf{t}^{*}\right)$ & Cornell University, Ithaca, NY, USA (D. Darling and J. Schafrik). \\
\hline DEl (t*) & $\begin{array}{l}\text { Institut für Pflanzenschutzforschung [formerly Deutsches Entomologisches } \\
\text { Institut], Kleinmachnow, Eberswalde, DDR (J. Oehlke). }\end{array}$ \\
\hline FSCA* & $\begin{array}{l}\text { Florida State Collection of Arthropods, Florida State Department of Agriculture } \\
\text { and Consumer Services, Gainesville, FL, USA (J. Wiley). }\end{array}$ \\
\hline GPC* & M.J. Gijswijt collection (private), Ankeven, Netherlands. \\
\hline IEEM (t) & Instituto Español de Entornología, Madrid, Spain. \\
\hline $\mathbf{I M L}\left(\mathbf{t}^{*}\right)$ & $\begin{array}{l}\text { Fundación e Insituto Miguel Lillo, Universidad Nacional de Tucumán, San } \\
\text { Miguel de Tucumán, Argentina (P. Fidalgo). }\end{array}$ \\
\hline INHS* & Illinois Natural History Survey, Champaign, $\amalg$, USA (W. LaBerge). \\
\hline IRSN* & Institut Royal des Sciences Naturelles, Brussels, Belgium (P. Dessart). \\
\hline $\mathbf{K H P C}\left(\mathbf{t}^{*}\right)$ & Karl-J. Hedqvist collection (private), Stockholm, Sweden. \\
\hline LACM* & $\begin{array}{l}\text { Los Angeles County Museum of Natural History, Los Angeles, CA, USA (R. } \\
\text { Snelling). }\end{array}$ \\
\hline $\operatorname{MAKB}(\mathbf{t})$ & Zoologisches Forschungsinstitut und Museum "Alexander Koenig", Bonn, BRD. \\
\hline $\operatorname{MBR}(\mathbf{t})$ & $\begin{array}{l}\text { Museo Argentino de Ciencias Naturales "Bernardino Rivadavia”, Buenos Aires, } \\
\text { Argentina. }\end{array}$ \\
\hline $\mathbf{M C Z}^{*}$ & $\begin{array}{l}\text { Museum of Comparative Zoology, Harvard University, Cambridge, MA, USA } \\
\text { (N. Stone). }\end{array}$ \\
\hline MHNG (t*) & Musum d'Histoire Naturelle, Geneva, Switzerland (I. Lobl). \\
\hline $\operatorname{MLP}\left(\mathbf{t}^{*}\right)$ & $\begin{array}{l}\text { Facultad de Ciencias Naturales y Museo, Universidad Nacional de La Plata, La } \\
\text { Plata, Argentina (L. De Santis). }\end{array}$ \\
\hline MNHP ( $(*)$ & Museum National d'Histoire Naturelle, Paris, France (S. Kelner-Pillault). \\
\hline $\operatorname{MPM}\left(\mathbf{t}^{*}\right)$ & Milwaukee Public Museum, Milwaukee, WI, USA (G. Noonan). \\
\hline MRAC* & Musée Royal de l'Afrique Centrale, Tervuren, Belgium (E. De Coninck). \\
\hline MSNG (t*) & Museo C \\
\hline
\end{tabular}




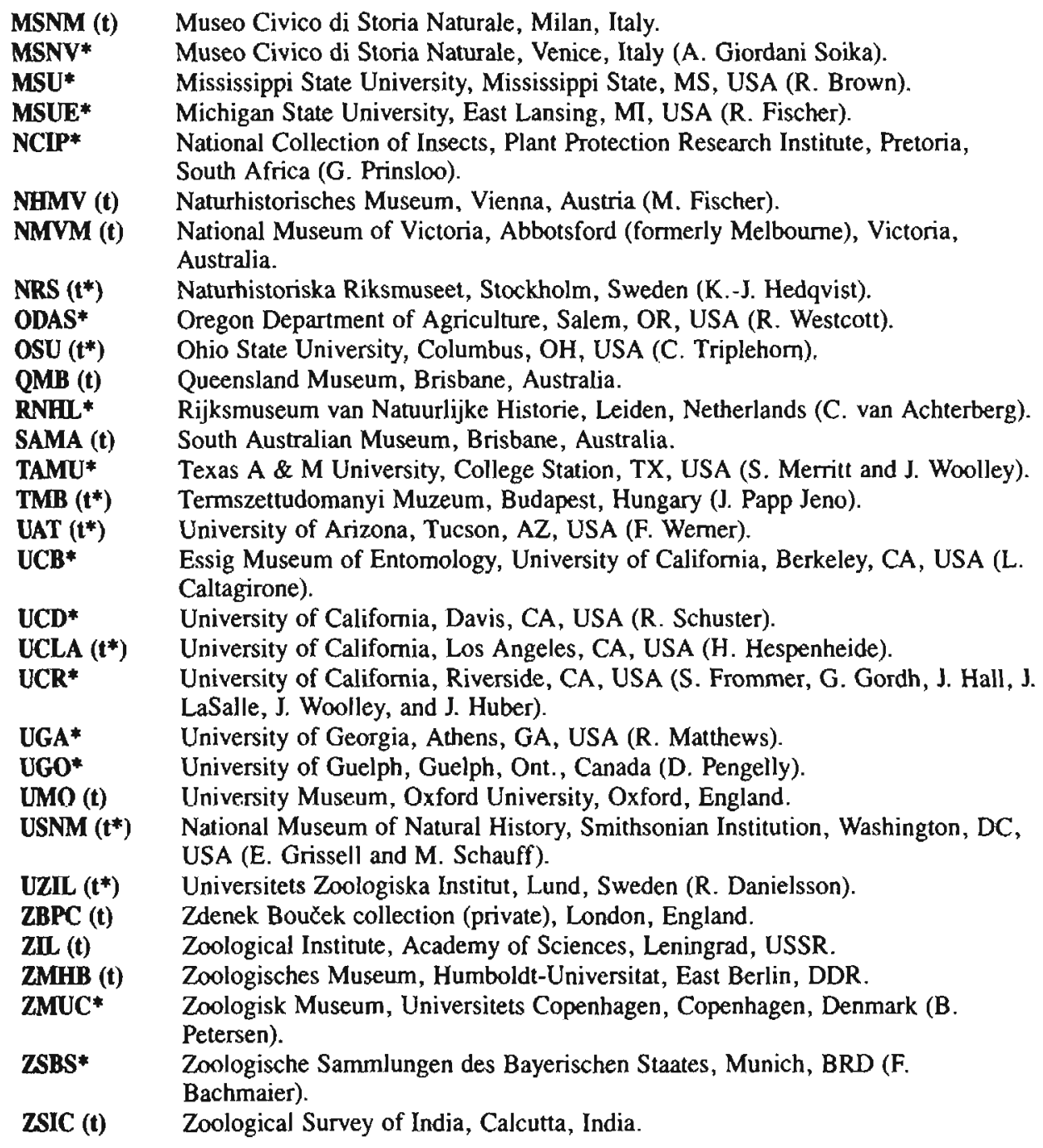

\section{METHODS}

\section{DESCRIPTIVE TAXONOMY}

Only the type species of a new genus is described, but the generic description encompasses recognized variation in character states when specimens representing undescribed species were known to me. Collection data of such specimens and the museums in which they are located are given in the section on "Diversity and distribution". Diagnostic features of each genus, including character states that indicate monophyly of the genus, are given in the section on "Monophyly and recognition". A list of species is given for previously described genera, including both taxa that were described in and those that were transferred to the genus. A synopsis of the nomenclatural history of each species, with the authority for transfers (comb.) or synonyms (syn.) is also given. Depository of primary type material is listed for each species, if known, and the taxon is denoted by an asterisk $\left(^{*}\right)$ if type specimens were examined. The country from which the species was described is also given. 
lateral edges of $\mathrm{Mt}_{5}-\mathrm{Mt}_{7}$ from apex of hypopygium to apex of $\mathrm{Mt}_{7}$; presumptive $\mathrm{Mt}_{9}$ spatulate, evenly convex. Cercus peg-like, at extreme anterolateral comer of presumptive $\mathrm{Mt}_{\text {g }}$. Metasoma of males 8-segmented; relatively shorter than in females, either elongatelanceolate with dorsum flattened (more or less triangular in cross-section) or cylindrical; petiole much narrower than in females but longer and trapezoidal; postpetiolar terga unmodified, with posterior edges entire and transverse; $\mathrm{Mt}_{8}$ and $\mathrm{Mt}_{9}$ indistinguishably fused as syntergum.

Hosts. Unknown but most likely xylophagous beetles (Coleoptera).

Diversity and Distribution. New World; in addition to the type species from the southwestern United States and northwestern Mexico I saw specimens from Mexico [Sinaloa, Mazatlan, 10.V.1961, Howden and Martin, at light $(1 \delta, C N C)$ ] and from Brazil [Nova Teutonia, 16.XII.1941, F. Plaumann $(19,2 \delta \delta$, AEI)] that represent two undescribed species.

\section{Archaeopelma tropeotergum sp.nov.}

(Figs. 3, 4, 27, 73, 99, 139)

Type Material. HOLOTYPE (female): Texas, Starr Co., 31.III.1960; D.J. and J.N. Knull Collrs. (OSU). ALLOTYPE (male): Arizona, $17 \mathrm{mi}$. SW Cortaro, 2600', 8.V.1961, R.H. and E.M. Painter (UAT). PARATYPES $\left(6 \delta^{\circ} \delta^{\circ}, 1 \%\right)$ : $5 \delta^{\circ} \delta^{\circ}$, same data as allotype. Texas, Hidalgo Co., 26.III.1957, D.J. and J.N. Knull Collrs. (1 $\$$, OSU). Mexico, Baja Calif. Sur, 10 mi. SE La Paz, 3. VIII. 1966, P.D. Hurd Collector, Colubrina glabra (1 $\delta^{*}$, deposited in CAS by request of UCB).

Condition of Holotype. Entire; mesonotum in unflexed position but obliquely pinned through mesoscutum and acropleuron, with left side of mesosoma broken, distended and exposing large axillar phragmata and $\mathrm{t}_{2}-\mathrm{tr}_{2}$ muscle.

Etymology. From the Latin words tropeos, keel, and tergum, back, referring to the shape of the presumptive $\mathrm{Mt}_{8}$ of females.

Description. FEMALE (holotype). Length $=0.92 \mathrm{~cm}$. HEAD green with parascrobal area in part and oval region between ocelli coppery-colored; relative measurements: HW $=16.2, \mathrm{HH}=14.1, \mathrm{HL}=9.9$, with frontal aspect relatively evenly convex, slightly protuberant lateral to interantennal area but upper parascrobal area not differentiated, parascrobal area about 1.75 times as wide as scrobes (measured at midheight) and not distinctly narrowed above toruli; interantennal area and narrow band below granulate, rugulose-reticulate below toruli but increasingly isodiametric-reticulate over parascrobal area (maximum size of cells about 0.5 ), reticulations smaller dorsally near ocelli and on vertex, occiput more reticulate-alutaceous; setae inserted at juncture of cells, white, unmodified and relatively long on occiput, vertex, and genae, but translucent-whitish and flattened, lanceolate to spatulate on frontal aspect of head and on parascrobal area. Ocelli with POL $=2.8, \mathrm{LOL}=1.0, \mathrm{OOL}=1.0$. Eye oval, $\mathrm{H}: \mathrm{W}=9.1: 6.7$; distance between eyes below $=12.2$, above $=6.8$. Scrobes elongate-slender, $\mathrm{H}: \mathrm{W}=9.2: 2.0$; isodiametric-reticulate within channel above interantennal area, cells much smaller than on parascrobal area. Antenna with scape and pedicel yellowish, flagellum dark brown with obscure metallic luster at some angles; inserted in line with ventral eye orbits, distance between ventral edge of toruli and clypeal edge compared with malar space $=4.0: 4.9$; scape elongatecylindrical, curved; $\mathrm{f}_{2}$ slightly widened to apex, and $\mathrm{fl}_{3}$ and $\mathrm{fl}_{4}$ slightly expanded dorsobasally; relative measurements of articles: $9.6(0.9) ; 2.0(1.1) ; 0.7(0.9), 4.8(1.3), 5.0(1.4)$, 4.2(1.5), 3.5(1.2), 3.1(1.0), 2.6(1.0), 2.4(1.1), [3.5(1.4)]. Mouthparts brown, except stipes greenish and labrum yellow.

MESOSOMA primarily dull greenish but with coppery-violaceous regions (particularly dorsum of pronotum and along notauli), more bluish-violaceous on propodeum, tegula 
yellow; relatively evenly setose with unmodified white setae, except metanotum, plical region of propodeum, acropleuron, and mesepimeron glabrous. Pronotum with isodiametric-reticulate sculpture on sides but isodiametric-coriaceous dorsolaterally to reticulate medially; shallowly, transversely concave posteriorly. Mesothorax with mesonotum and prepectus isodiametric-reticulate, cells of similar size throughout and of similar size to those on parascrobal area; lower mesepisternum alutaceous to coriaceous; upper mesepisternum reticulate to rugulose-reticulate; acropleuron punctate-reticulate centrally but more punctulate along edges; acropleural sulcus and mesopleural suture costate; upper mesepimeron smooth and shining; lower mesepimeron isodiametric-reticulate ventrally but gradually more coriaceous dorsally to smooth and shining near dorsal edge; scutellaraxillar complex quadrate, medial length of scutellum to width of complex $=9.2: 9.0$. Mctathorax with pleuron rugulose-reliculate, similar to callar region of propodeum; dorsellum rugulose, length to medial length of propodeum $=0.7: 3.1$. Propodeum with plical region costulate along anterior edge, otherwise isodiametric-reticulate with cells deeper and smaller than those on mesonotum and punctulate-rugulose laterally near spiracle; callar regions rugulose-reticulate. Wings hyaline but with brownish trace veins and yellowishbrown venation; fore wing with $S M V=24.0, \mathrm{MV}=8.6, \mathrm{PMV}=16.2, \mathrm{STV}=3.0$. Legs yellowish except coxae green and outer femoral surfaces with slight bluish luster; protibia with 4 (left tibia) and 5 (right tibia) denticle-like spicules along dorsal surface; middle leg with tibia $=16.8$, tarsomeres $=9.3,2.2,1.5,1.2,0.9$; metatibia with 2 spine-like spicules along dorsal surface.

METASOMA dark green with coppery violaceous reflections, particularly on presumptive $\mathrm{Mt}_{8}$ and base of $\mathrm{Mt}_{7}$, when viewed at different angles; relatively evenly setose with unmodified white setae except petiole- $\mathrm{Mt}_{3}$ glabrous dorsally. Petiole transversely costulate along anterior edge, length to width $=1.0: 7.3 ; \mathrm{Mt}_{2}$ smooth and shining dorsally, except obscurely coriaceous laterally and rugulose-reticulate on sides; $\mathrm{Mt}_{3}$ mostly concealed under $\mathrm{Mt}_{2}$ and difficult to distinguish dorsally (see section on "Variation") but sides rugulose-reticulate; $\mathrm{Mt}_{4}$ smooth along anterior and posterior edges but about medial 0.5 punctate-reticulate to isodiametric-reticulate, sides rugulose-reticulate; $\mathrm{Mt}_{5}$ isodiametric-reticulate, except smooth along anterior edge and sides rugulose-reticulate; $\mathrm{Mt}_{6}$ punctate-reticulate anteriorly but gradually more coriaceous posteriorly, with posterior edge smooth and sides rugulose-reticulate; $\mathrm{Mt}_{\mathbf{7}}$-syntergum isodiametric-coriaceous dorsally and ventrally, except concave sides of presumptive $\mathrm{Mt}_{8}$ vertically wrinkled distal to $\mathrm{Mt}_{7}$; presumptive $\mathrm{Mt}_{9}$ with sides subparallel over most of length, 3.3 times as long as anterior width; relative length of terga: $1.0(\mathrm{~m}), 8.2(\mathrm{pm}), 1.3(\mathrm{~m}), 5.6,7.8,15.0,16.5,[7.0,7.0]$. Hypopygium small, extended to level about midway between apices of $\mathrm{Mt}_{4}$ and $\mathrm{Mt}_{5}$. Ovipositor sheaths dark brown, slightly (3.0) exserted beyond apex of syntergum.

MALE (allotype). Length $=0.49 \mathrm{~cm}$. HEAD (Figs. 3, 4) blue with violaceous reflections; structure similar to female except relative measurements: $\mathrm{HW}=10.7, \mathrm{HH}=9.4$, $\mathrm{HL}=7.1$, with upper parascrobal area differentiated as elongate-rectangular, minutely transverse-reticulate or somewhat imbricate black region that is slightly convex along inner eye orbit and protuberant anterior to posterior ocellus, parascrobal area only about 0.75 as wide as scrobes at midheight; setation similar to female except setae on frontal aspect less conspicuously flattened. Ocelli with $\mathrm{POL}=3.0, \mathrm{LOL}=1.3, \mathrm{OOL}=0.7$. Eye oval, $\mathrm{H}: \mathrm{W}=6.4: 3.9$. Scrobes (Figs. 3,4) similar to female except relatively much shorter and wider, $\mathrm{H}: \mathrm{W}=5 \cdot 3: 2.5$. Antenna black, except radicle yellowish-brown and scape with bluish luster; inserted distinctly above line drawn between ventral eye orbits, distance between ventral edge of toruli and clypeal edge compared with malar space $=3.8: 2.9$; scape cylindrical, relatively much shorter and stouter than in female; relative measurements of articles: $4.0(1.0) ; 1.0(1.0) ; 0.3(0.8), 3.0(1.8), 4.5(2.0), 4.7(2.0), 4.0(1.9), 3.5(1.8)$, $3.2(1.7), 2.8(1.5),[3.2(1.4)]$. 
MESOSOMA bluish with violaceous reflections, tegula yellow; setation similar to female except longer. Mesothorax (Figs. 27, 73) with sculpture similar to female except as follows: dorsum of pronotum same isodiametric-reticulate as rest of mesonotum, acropleuron isodiametric-reticulate except posterodorsal region smooth and shining and upper mesepimeron obscurely coriaceous; scutellar-axillar complex relatively much longer than in females, length of scutellum to width of complex $=7.8: 6.2$. Propodeum most conspicuously costulate anterolaterally; plical region isodiametric-reticulate with cells much shallower than on mesoscutum, almost coriaceous; medial length of dorsellum to propodeum $=0.9: 2.6$. Wings superficially glabrous but with very sparse and short discal setae; hyaline, without trace veins; venation dark brown, except PMV gradually depigmented distally (see section on "Variation"); fore wing with SMV $=15.2, \mathrm{MV}=4.7, \mathrm{PMV}=$ $5.0, \mathrm{STV}=1.5$. Legs with coxae and femora bluish; trochanters and tibiae brownish with slight bluish luster, except tibial-femoral joints yellowish; each tarsus with basitarsus mostly white, apex of basitarsus and subsequent tarsomeres brownish; protibia with 6 (left tibia) and 5 (right tibia) denticle-like spicules along dorsal surface; middle leg with tibia $=9.3$, tarsomeres $=3.5,1.1,1.0,0.6,0.9$; hind tibia with 2 subbasal and 1 more apical spinelike spicules along dorsal surface.

METASOMA with bluish luster dorsally except $\mathrm{Mt}_{2}$ dark brown, $\mathrm{Mt}_{7}$ violaceous and syntergum greenish, sides of metasoma dark brown with brassy luster. Petiole smooth and shining; $\mathrm{Mt}_{2}$ shining dorsally and almost smooth but with very fine coriaceous sculpture; $\mathrm{Mt}_{3}-\mathrm{Mt}_{6}$ isodiametric-reticulate with cells more distinctly defined toward median than laterally and with terga smooth along anterior edges; $\mathrm{Mt}_{7}$ coriaceous; syntergum very finely coriaceous; $\mathrm{Mt}_{2}$ to syntergum with sides alutaceous; relative length of terga: $1.0(\mathrm{~m}), 5.1$, 2.0, 4.3, 5.0, 5.6, 4.0, 1.5.

Variation. The single female paratype is broken, with the antennae and middle legs missing. It is slightly larger than the holotype (approximately $1 \mathrm{~cm}$ in length) and is similar in color except that the entire body is more distinctly coppery. Structure and sculpture are also similar except that each protibia has 4 dorsal denticles, and $\mathrm{Mt}_{3}$ is more conspicuously exposed (slightly greater than 0.5 length of $\mathrm{Mt}_{4}$ and about 0.4 length of $\mathrm{Mt}_{2}$ ), asetose, and only obscurely coriaceous.

As for females, males have $\mathrm{Mt}_{3}$ overlapped by $\mathrm{Mt}_{2}$ to differing extents. Though the dorsal length of $\mathrm{Mt}_{3}$ varies as a result, it is distinctly less than $\mathrm{Mt}_{2}$ or $\mathrm{Mt}_{4}$. The smallest male is $0.35 \mathrm{~cm}$, the largest is $0.55 \mathrm{~cm}$. There are also differences in pigmentation of the PMV; if only the "brownish" part is measured the vein is superficially shorter than the MV, but actually is up to 1.25 times as long as the latter vein. Number of denticles on the protibia varied from 4 to 7 , and the number usually differed on each tibia by 1 or 2 .

LICROOIDES GEN.NOV.

Genus B; Gibson, $1986 b$.

(Figs. 8, 9, 32, 54, 74, 100, 141)

Type Species. Licrooides umbilicatus sp.nov., by present designation.

Etymology. From the Greek words likros, antler, and eidos, like, referring to the antlerlike antennae of males. Gender: masculine.

Monophyly and Recognition. Monophyly of Licrooides is indicated by presence of a transepisternal sulcus (Fig. 32), which is autapomorphic within Calosotinae. Individuals are also readily distinguished from other calosotines by structure of their mesopleuron (Fig. 32).

Description. HEAD (Figs. 8, 9) with parascrobal area moderately raised, a single row of coarse rasp-like cristae along inner eye orbit. Scrobes separated ventrally for 0.5 length 


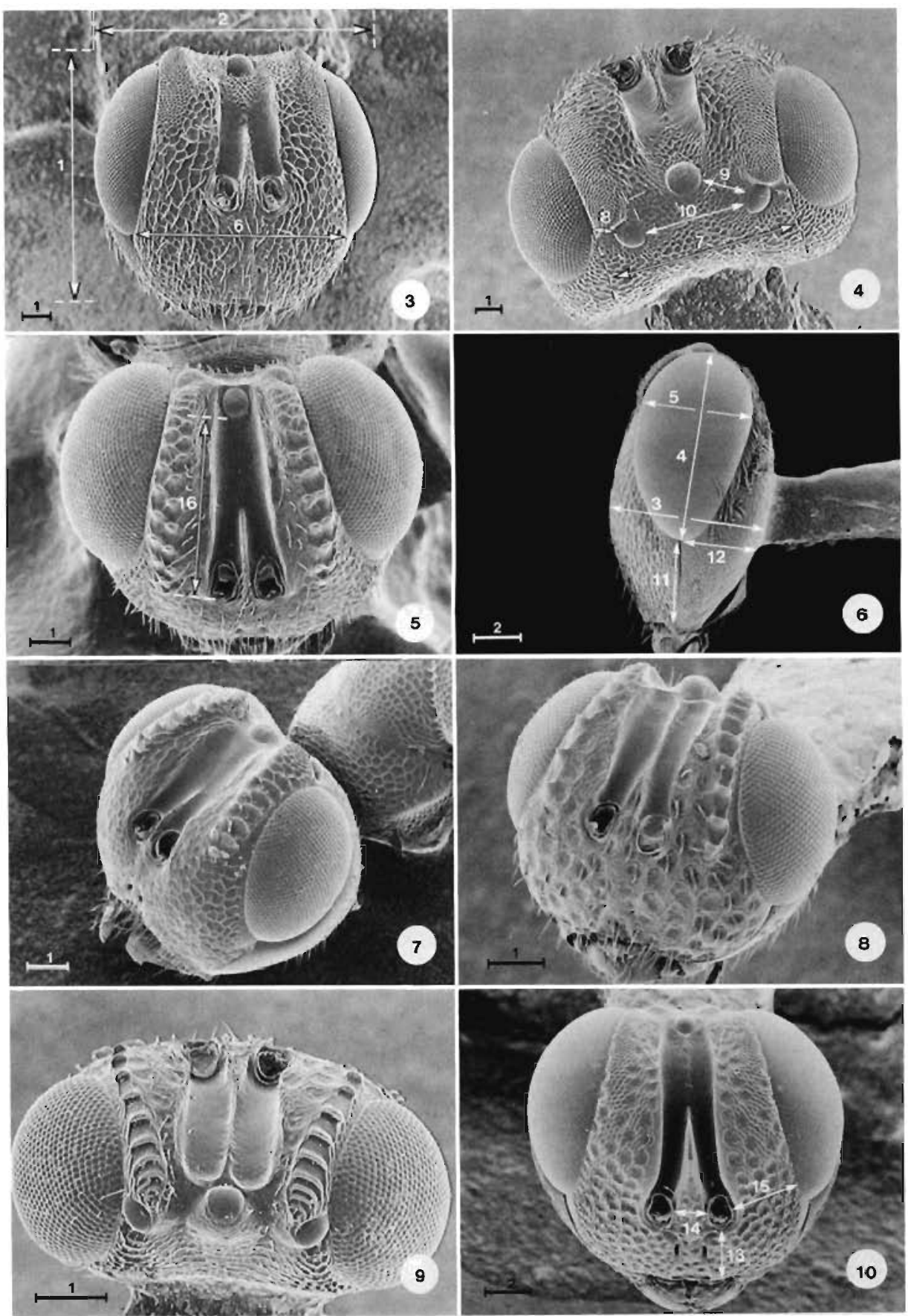

Figs. 3-10. (Scale bar $=\times 100 \mu \mathrm{m}$.) Head: 3, Archaeopelma tropeotergum sp.nov. ( $\delta$, frontal); 4 , A. tro. peotergum sp.nov. ( $\delta$, dorsal); 5, Eusandalum sp. ( $Q$, frontal); $6, E$. sp. ( $\$$, lateral); $7, E$. cyaneum (Ashmead)

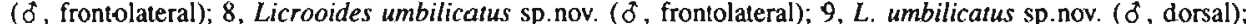
10, Balcha cylindrica Walker ( $\$$, frontal). [See "Methods" section for explanation of measurements denoted by number.] 

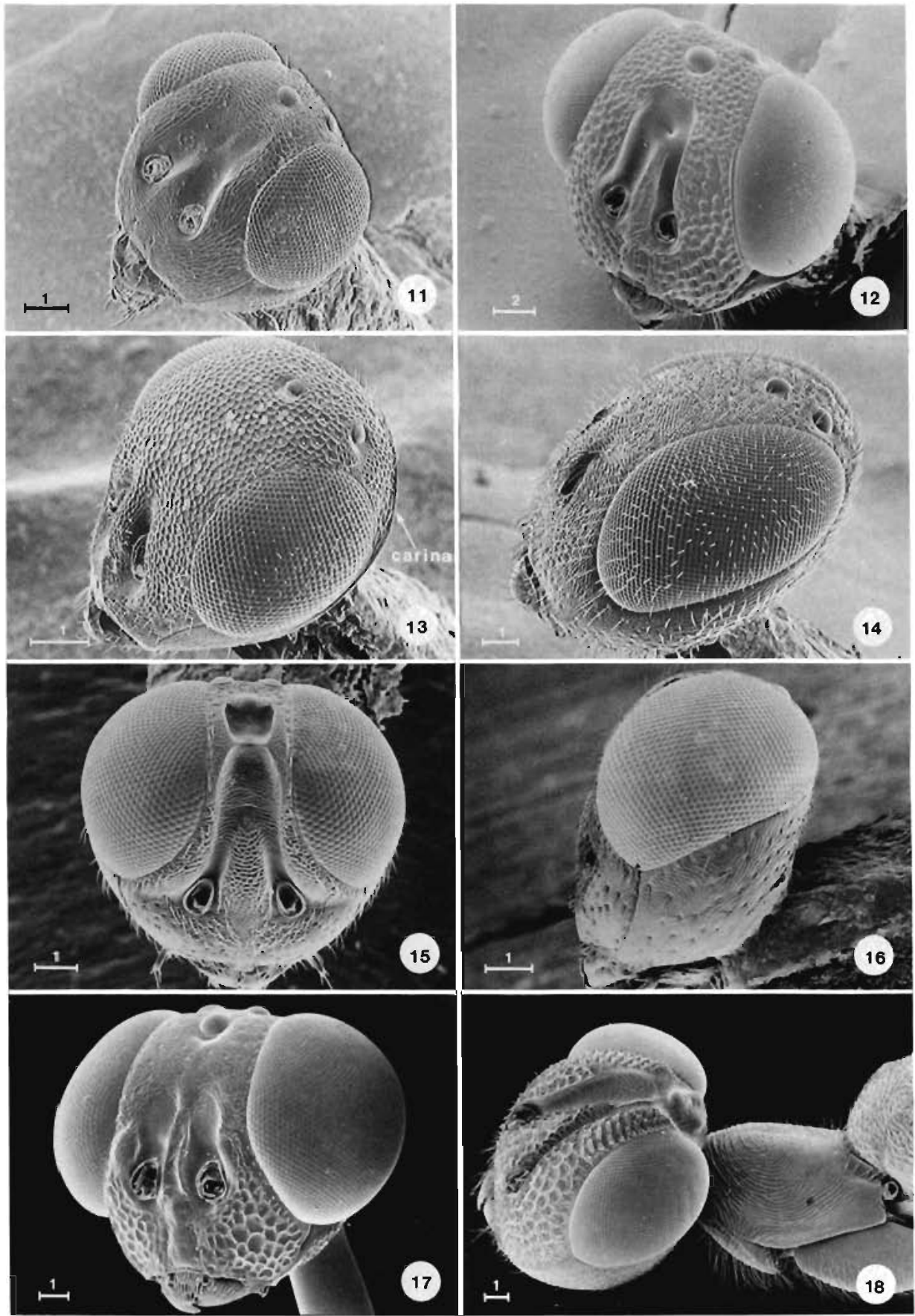

FiGs. 11-18. (Scale bar $=\times 100 \mu \mathrm{m}$.) Head, 9: 11, Calosota metallica Gahan (frontolateral); 12, C. sp. (frontolateral); 13, Neanastatus sp. (frontolateral); 14, Metapelma spectabile Westwood (frontolateral); 15 , Lambdobregma schwarzii (Ashmead) (frontal); 16, L. schwarzii (lateral); 17, Tanythorax spinosus sp. nov. (frontolateral); 18, Oodera sp. (frontolateral). 

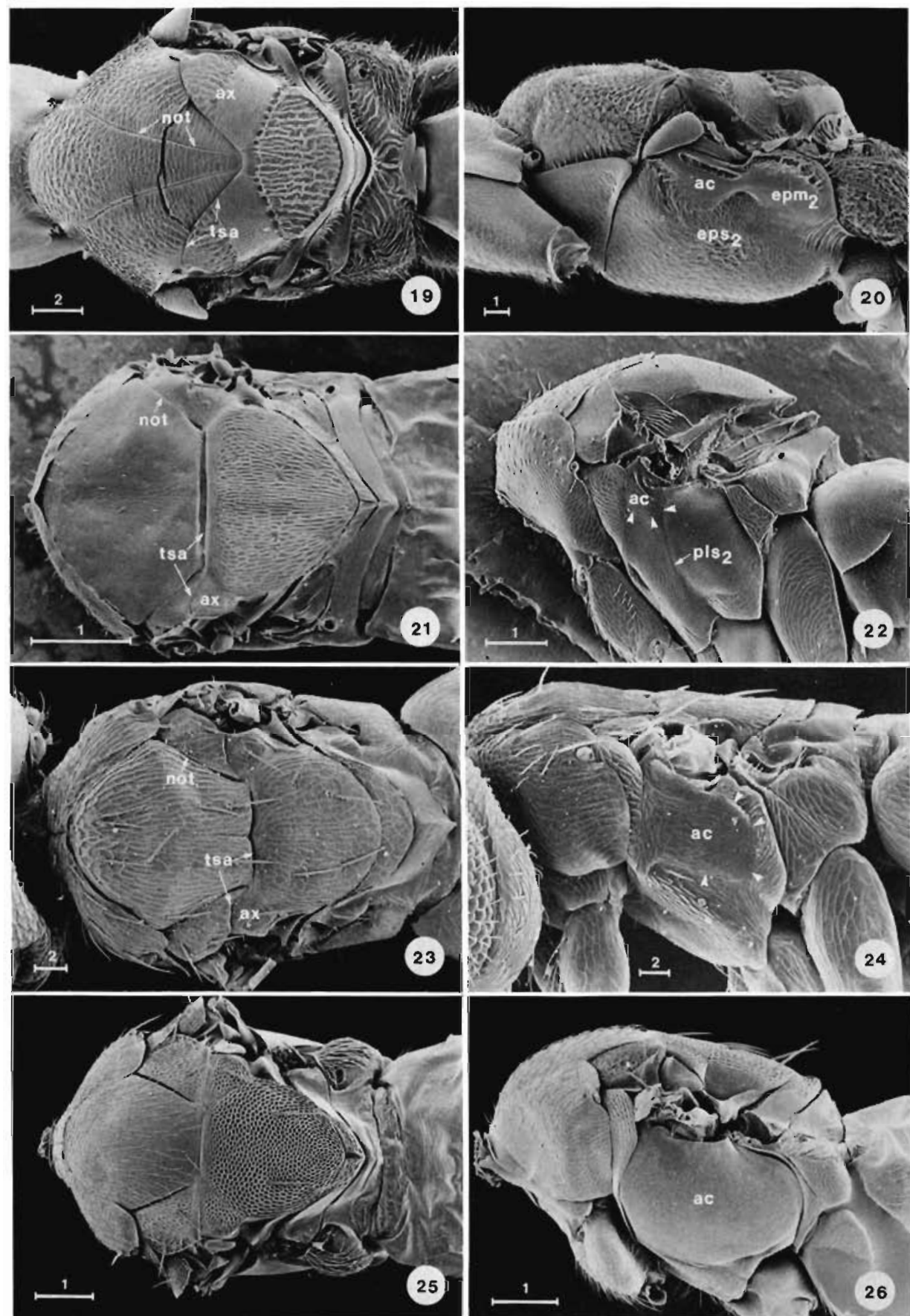

Figs. 19-26. (Scale bar $=\times 100 \mu \mathrm{m}$.) Mesosoma, $9: 19$, Oodera sp. (dorsal); $20, O . \mathrm{sp}$. (lateral); 21 Coccobius sp. (dorsal); 22, Coccophagus sp. (lateral); 23, Aphelinidae, genus indet. (dorsal); 24, Aphelinidae, genus indet. (lateral); 25, Eutrichosomella sp. (dorsal); 26, E. sp. (lateral). [Triangles demark limit of acropleuron in Figs.

$$
\text { 22, 24.] }
$$



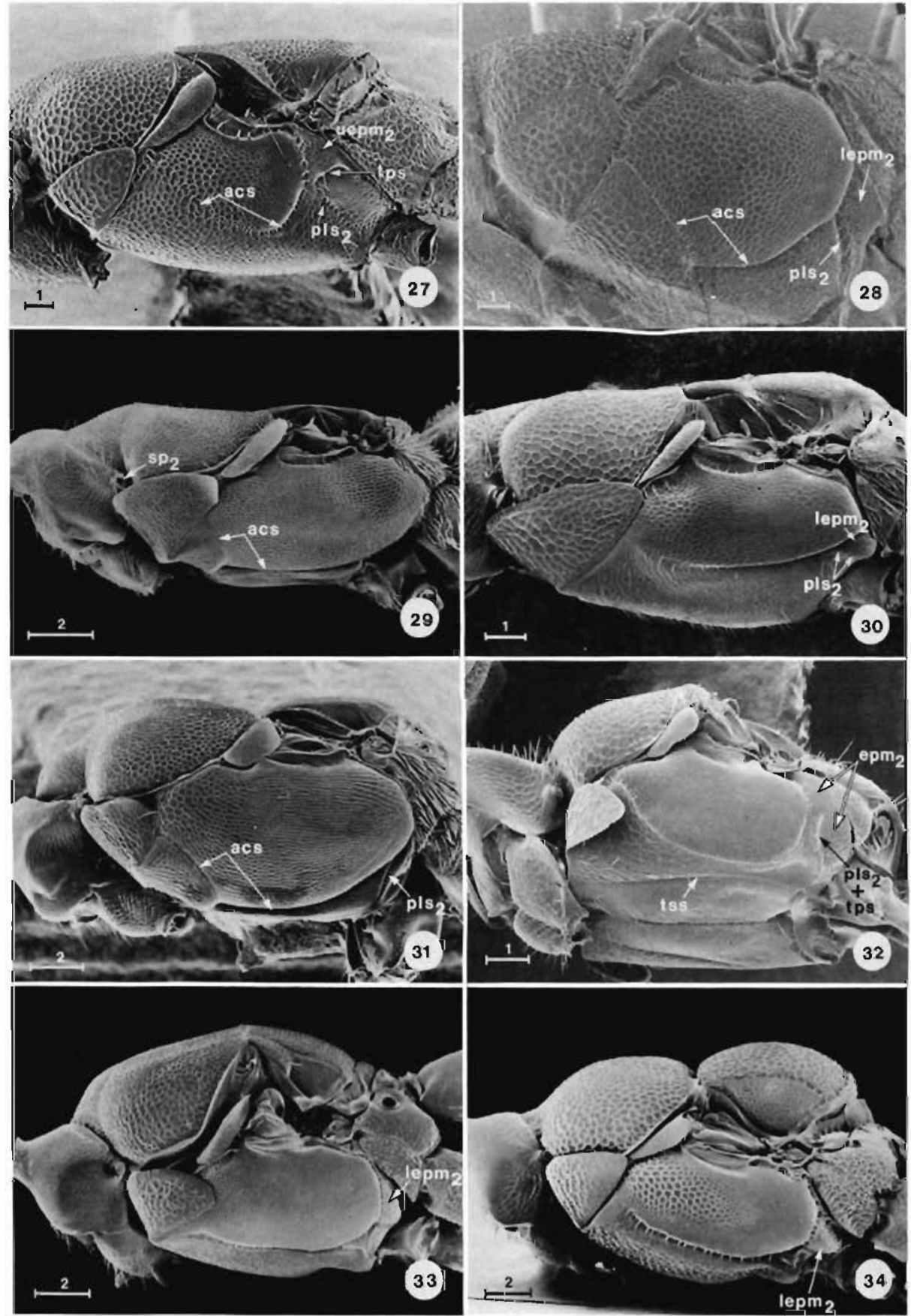

FIGs. 27-34. (Scale bar $=\times 100 \mu \mathrm{m}$.) Lateral mesosoma: 27, Archaeopelma tropeatergum sp.nov. ( $\left.{ }^{\circ}\right)$; 28 , Paraeusandalum chilense sp.nov. ( $Q$, uncoated paratype); 29, Eusandalum sp. ( $($ ); 30, E. cyaneum (Ashmead) $(\delta) ; 31$, Chirolophus eques Haliday ( $(9) ; 32$, Licrooides umbilicatus sp.nov. ( $\left.{ }^{(}\right) ; 33$, Calosota acron (Walker) (\$); 34, Calosota sp. (\$). 

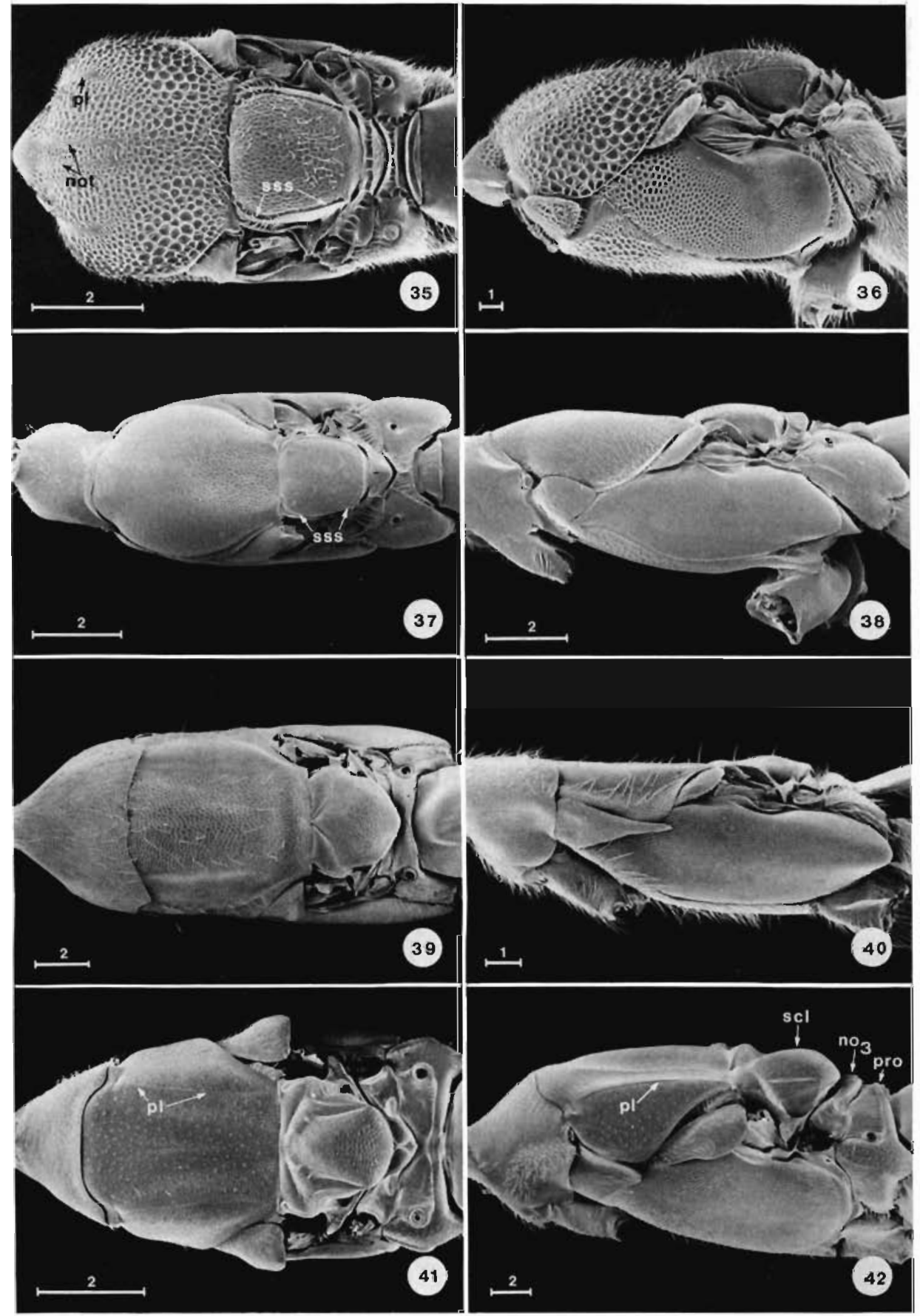

Figs. 35-42. (Scale bar $=\times 100 \mu \mathrm{m}$.) Mesosoma, $9: 35$, Balcha cylindrica Walker (dorsal); 36, B. cylindrica (lateral); 37, Tanythorax spinosus sp.nov. (dorsal); 38, $T$. spinosus (lateral); 39, Lambdobregma schwarzii (Ashmead) (dorsal); 40, L. schwarzii (lateral); 41, Metapelma specrabile Westwood (dorsal); $41, M$. spectabile (lateral). 

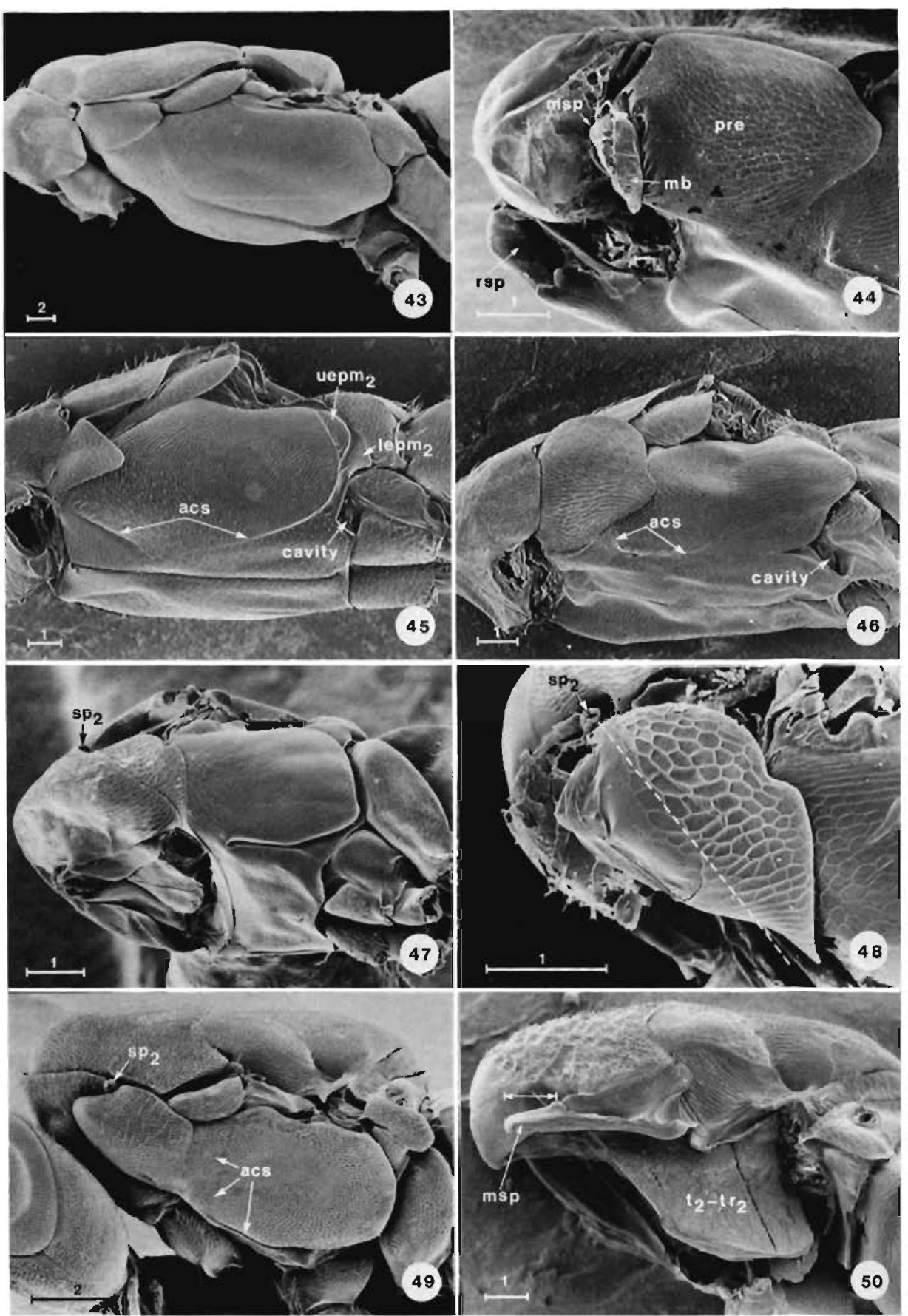

FiGs. 43-50. (Scale bar $=\times 100 \mu \mathrm{m}$.) $9: 43$, Brasema sp. (lateral mesosoma, unflexed); 44, Neanastatus sp. (frontolateral prepectus; pronotum and membrane from right prepectus removed); 45, Metapelma spectabile Westwood (lateral mesosoma, flexed); 46, Neanastalus sp. (lateral mesosoma, flexed); 47, Cynipencyrtus flavus Ishii (lateral mesosoma, flexed); 48, C. flavus (prepectus; pronotum removed); 49, Tanaostigmodes howardii Ashmead (lateral mesosoma, unflexed); 50, $T$. sp. (lateral mesosoma; prepectus and acropleuron removed). 

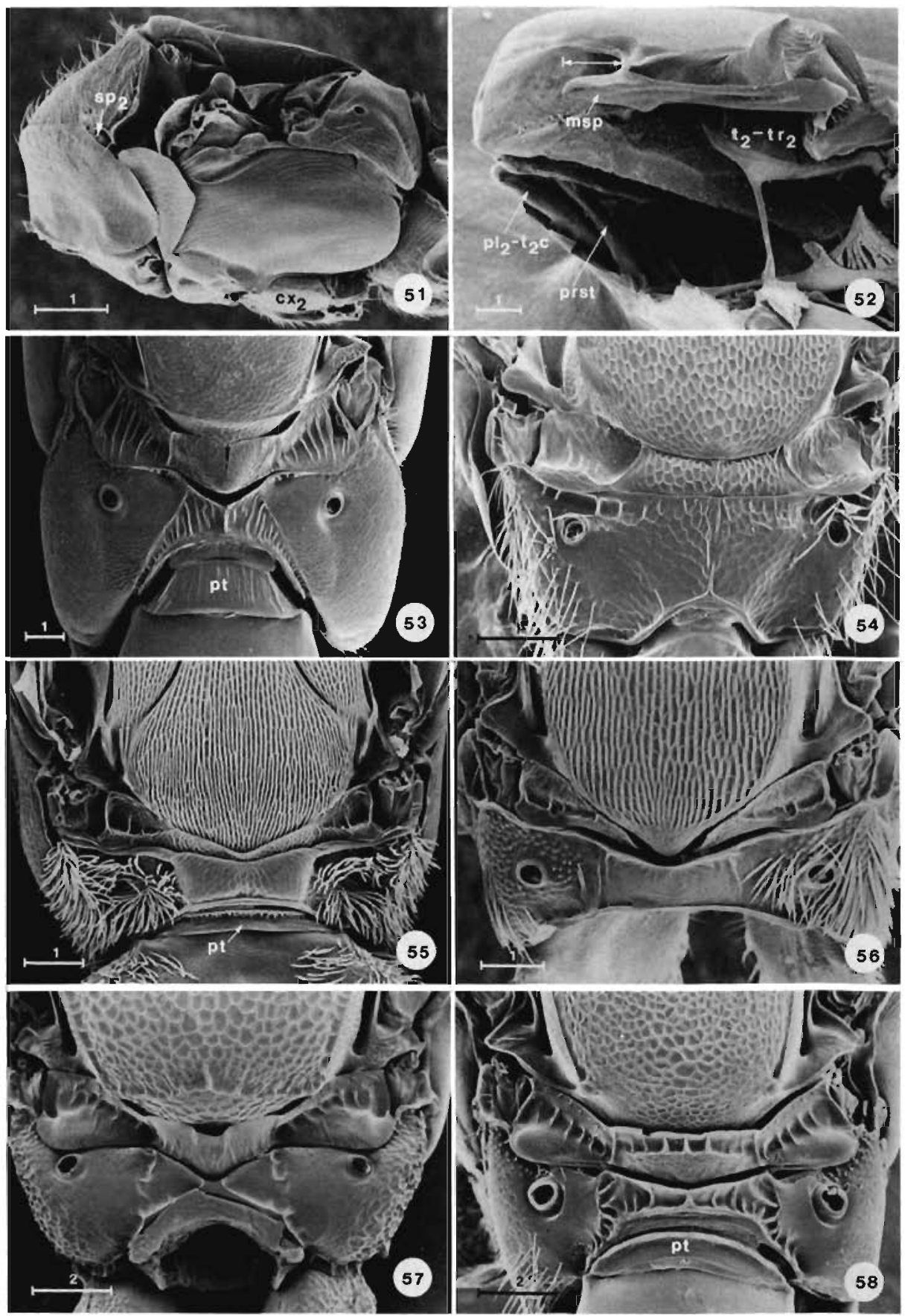

FIGs. 51-58. (Scale bar $=\times 100 \mu \mathrm{m}$.) 51 and 52, lateral mesosoma ( 8 ): 51, Clausenia purpurea Ishii (flexed); 52, Encyrtus fuscus (Howard) (pronotum, prepectus and acropleuron removed). 53-58, dorsal scutellar apexpropodeum: 53, Tanythorax spinosus sp.nov. ( 9 ); 54, Licrooides umbilicatus sp.nov. ( $\left.{ }^{\prime}\right) ; 55$, Eusandalum sp.

(१); 56. Chirolophus sp. (१); 57, Calosota sp. (१); 58, Balcha cylindrica Walker ( $($ ). 

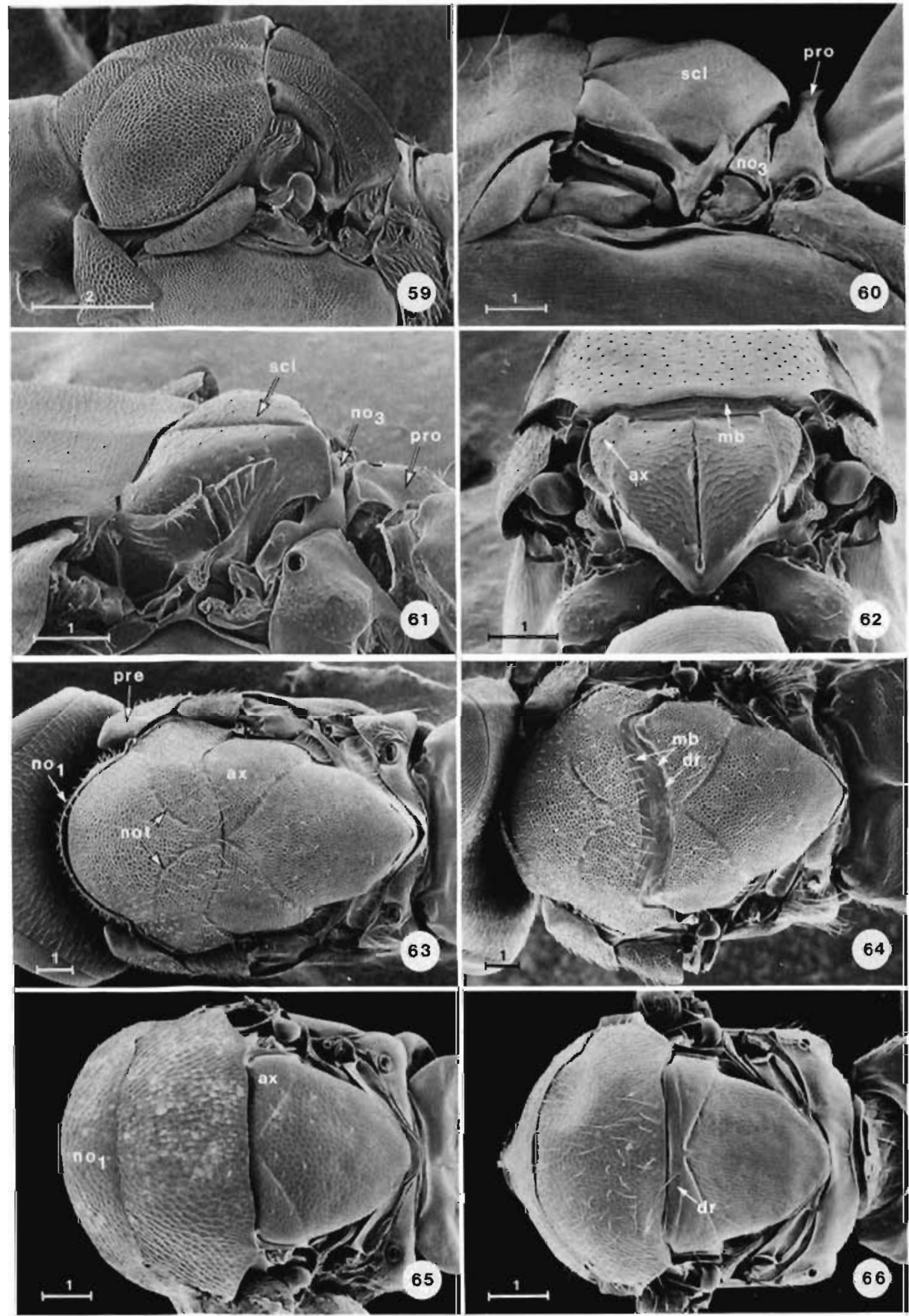

Fics. 59-66. (Scale bar $=\times 100 \mu \mathrm{m}$.) 59, Eusandalum sp. ( $\$$ ) (dorsolateral mesosoma, flexed). 60-62, posterior mesoscutum-propodeum ( 9 ): 60, Lambdobregma schwarzii (Ashmead) (dorsolateral, unflexed); 61, Neanastatus sp. (dorsolateral, unflexed); 61, Neanastatus sp. (posterodorsal, flexed). 63-66, dorsal mesosoma ( $\$$ ): 63, Tanaostigmodes howardii Ashmead (unflexed); 64, T. howardii (flexed); 65, Cynipencyrius fiavus Ishii (flexed); 65, Manicnemius indicus (Mani and Saraswat) (flexed). 

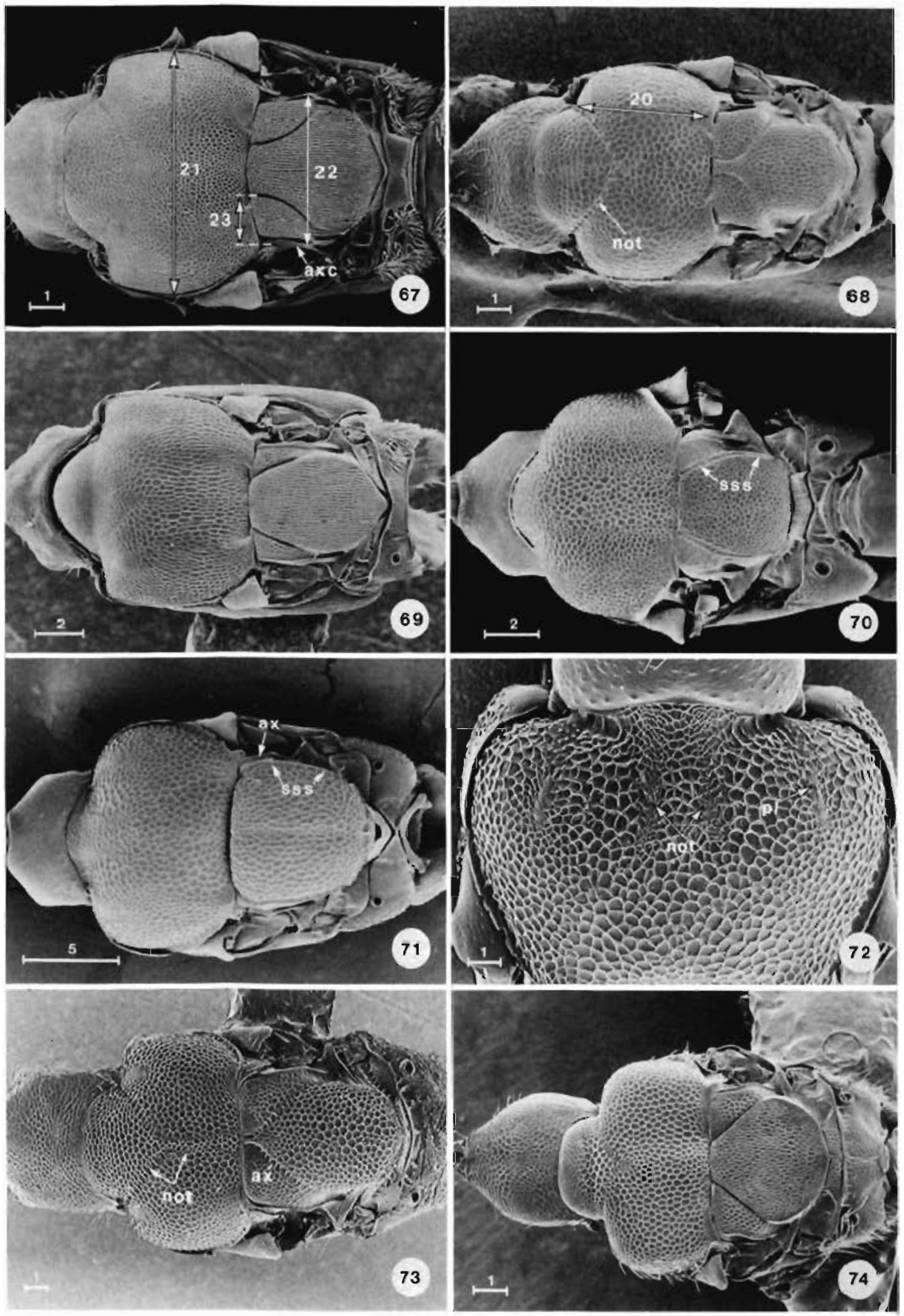

Figs. 67-74. (Scale bar $=\times 100 \mu \mathrm{m}$.) 67-71, dorsal mesosoma (unflexed): 67, Eusandalum sp. ( 9$) ; 68, E$. cyaneurn (Ashmead) ( $\$) ; 69$, Chirolophus eques Haliday ( $\$$ ); 70, Calosota acron (Walker) ( $($ ); 71 , Calosota sp. (\%). 72, Calosota sp. ( 9 ) (dorsal mesoscutum). 73 and 74, dorsal mesosoma ( $\delta$, unflexed): 73, Archaeopelma tropeotergum sp.nov.; 74, Licrooides umbilicatus sp.nov. [See "Methods" section for explanation of measurements denoted by number. 


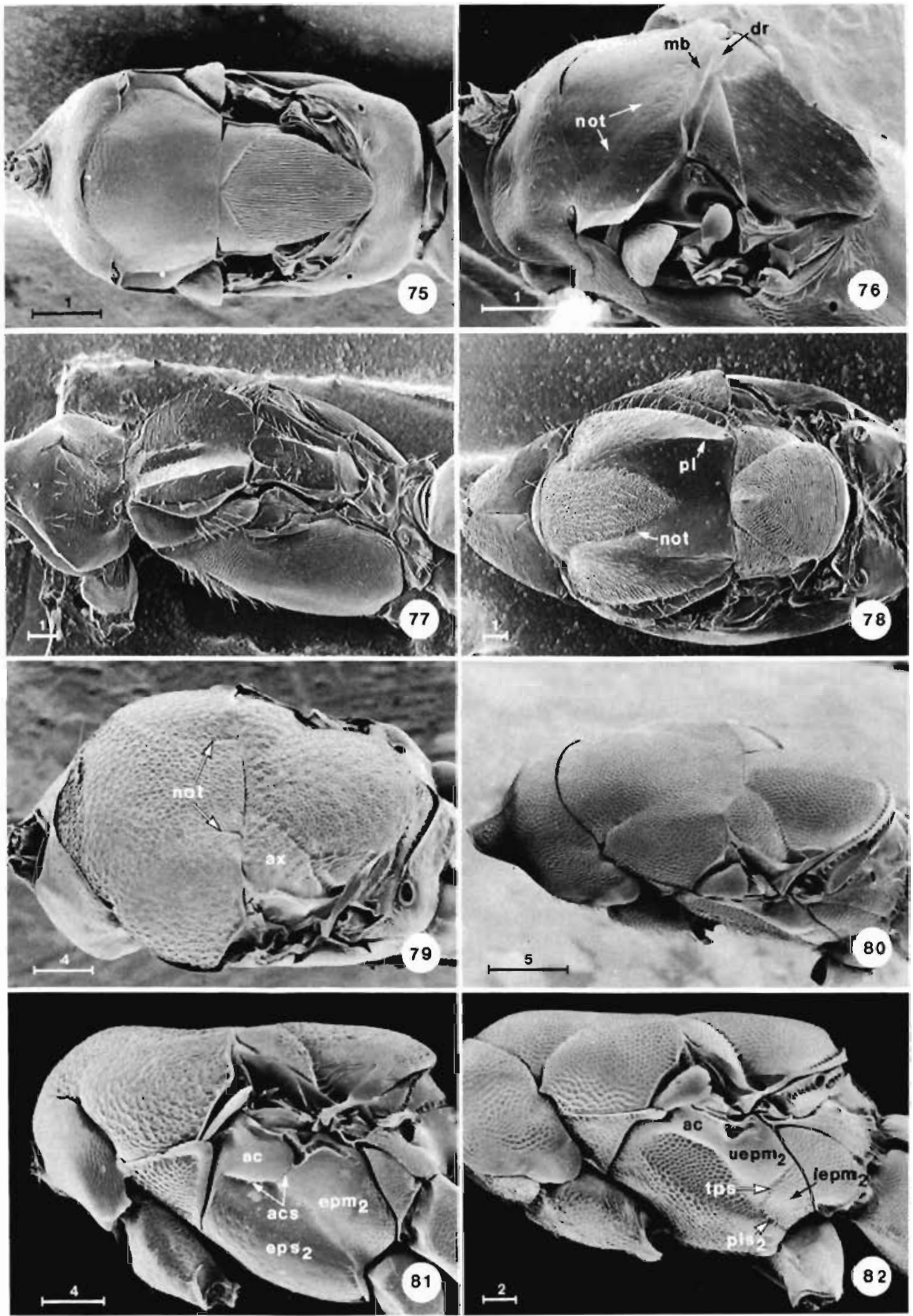

Fias. 75-82. (Scale bas $=\times 100 \mu \mathrm{m}$.) Mesosoma: 75, Charitopus sp. $(q$, dorsal, unflexed); 76, $C . \mathrm{sp} .(q$, dorsolateral, flexed); 77, Macroneura sp. ( $\$$, dorsolateral, unflexed); 78, Arachnophaga picea (Howard) ( $\%$. dorsal, unflexed); 79, Brasema sp. ( $\delta$, dorsolateral); 80, Lysisca sp. ( $\$$, dorsolateral); 81 , Brasema sp. ( $\delta$, lateral); 82, Lysisca sp. ( $\$$, lateral). 

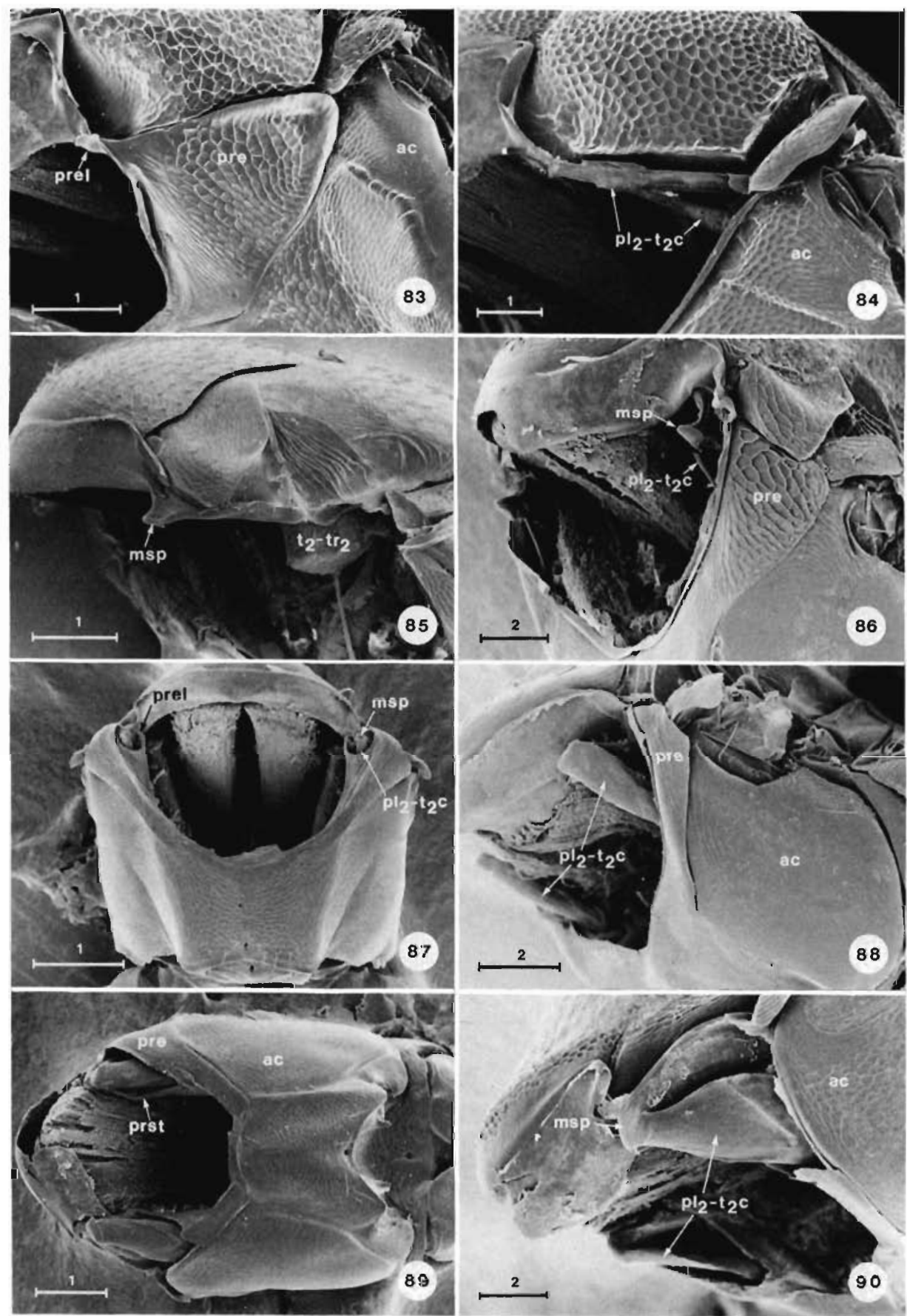

Figs. 83-90. (Scale bar $=\times 100 \mu \mathrm{m}$.) 83 and 84, Eupelmus sp. ( $\delta$, frontolateral mesothorax): 83 , pronotum removed; 84, pronotum and prepectus removed. 85, Coccophagus sp. ( $($ ) (lateral mesosoma; pronotum, prepectus, and mesopleuron removed). 86, Aphelinidae, genus indet. (\$) (frontolateral mesothorax; pronorum removed). 87, Aphelinus sp. ( $\$$ ) (ventral mesosoma; pronotum and coxae removed). 88, Coccobius sp. ( $\$$ ) (frontolateral mesothorax; pronotum removed). 89 and 90 . Eutrichosomella sp. ( $($ ): 89 , ventral mesosoma (pronotum ${ }_{3}$ coxae and right lateral prepectus removed): 90 . insertion of $\mathrm{pl}_{2}-t_{2} \mathrm{c}$ muscle (pronotum and lateral prepectal surface removed). 

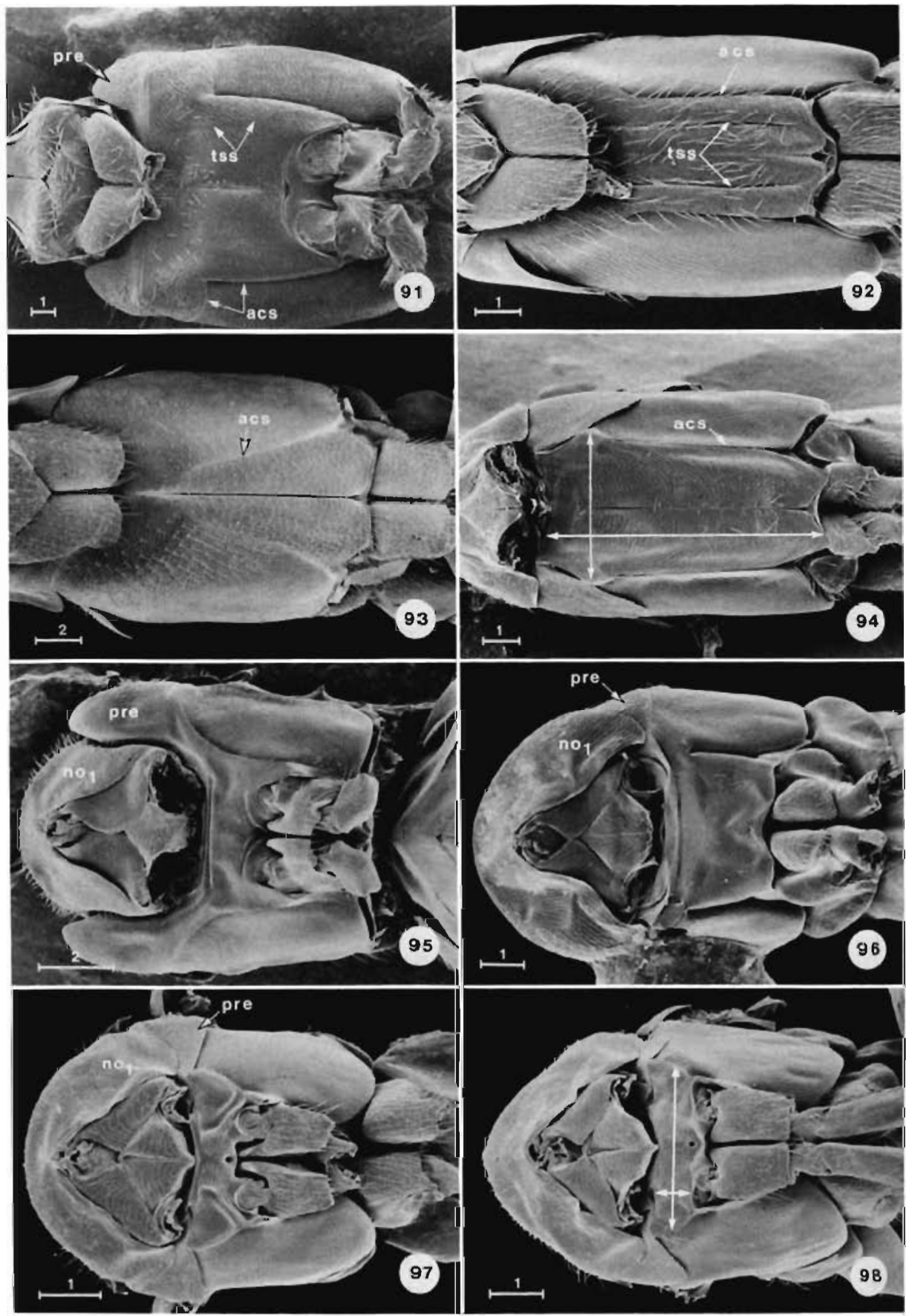

Figs. 91-98. (Scale bar $=\times 100 \mu \mathrm{m}$.) Ventral mesosoma: 91, Eusandalum sp. (8); 92, Lambdobregma schwarzii (Ashmead) ( 9 ); 93, Metapelma spectabile Westwood (\$); 94, Neanastatus sp. (ठ); 95, Tanaostigmodes albiclavus Girault ( 9 ); 96, Cynipencyrtus flavus Ishii (\$); 97, Manicnemius indicus (Mani and Saraswat) (\$); 98. Clausenia purpurea Ishii (?). [Arrows demark limits of mesepisterna in Figs. 94, 98.] 


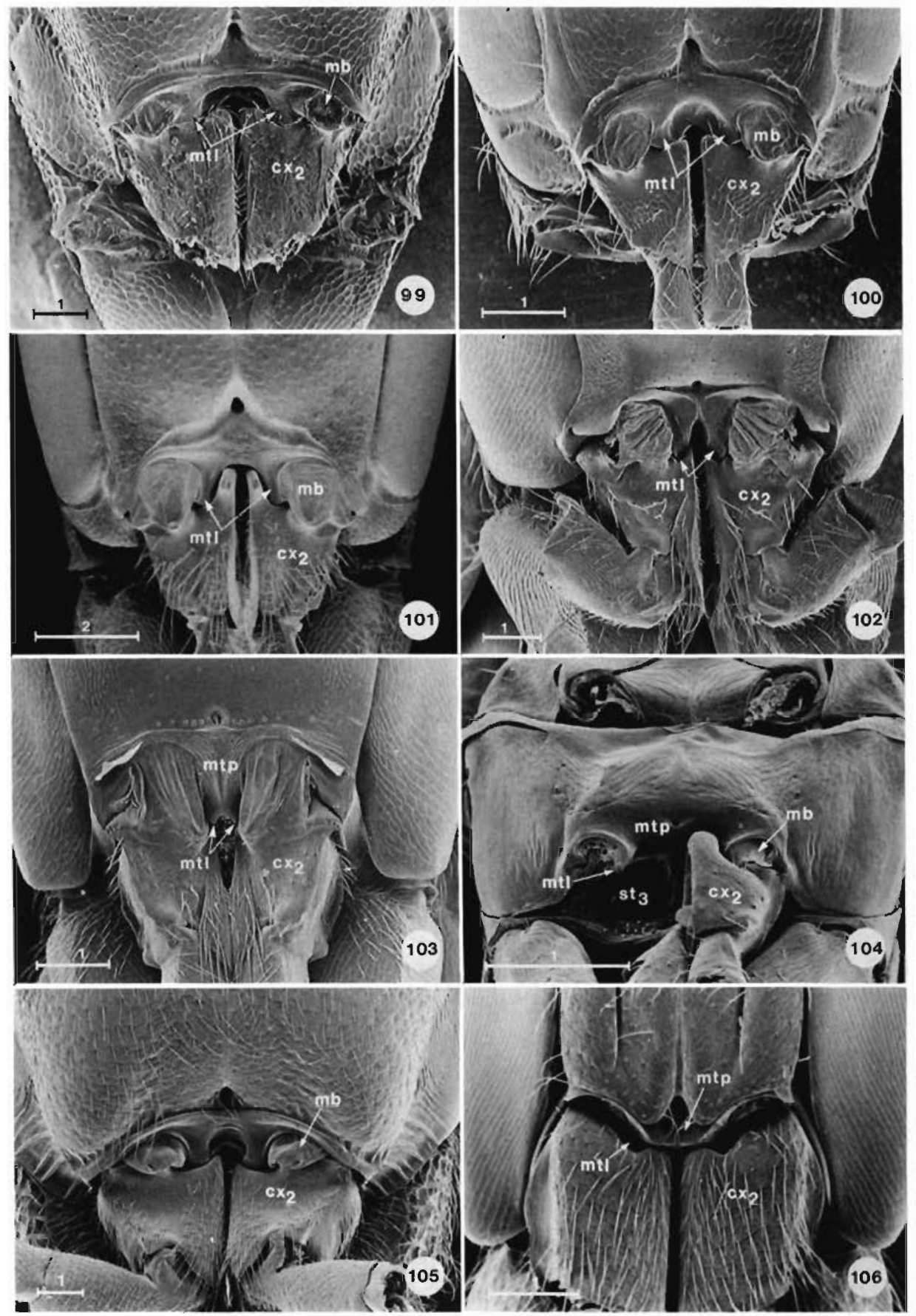

Fics. 99-106. (Scale bar $=\times 100 \mu \mathrm{m}$.) Ventral mesopleural-mesocoxal articulation: 99, Archaeopelma tro-

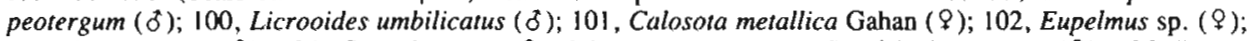
103, Brasema sp. (q); 104, Coccobius sp. (Q, right mesocoxa removed); 105, Ondera sp. (\$); 106, Iamhdobregma schwarzii (Ashmead) ( $($ ). 


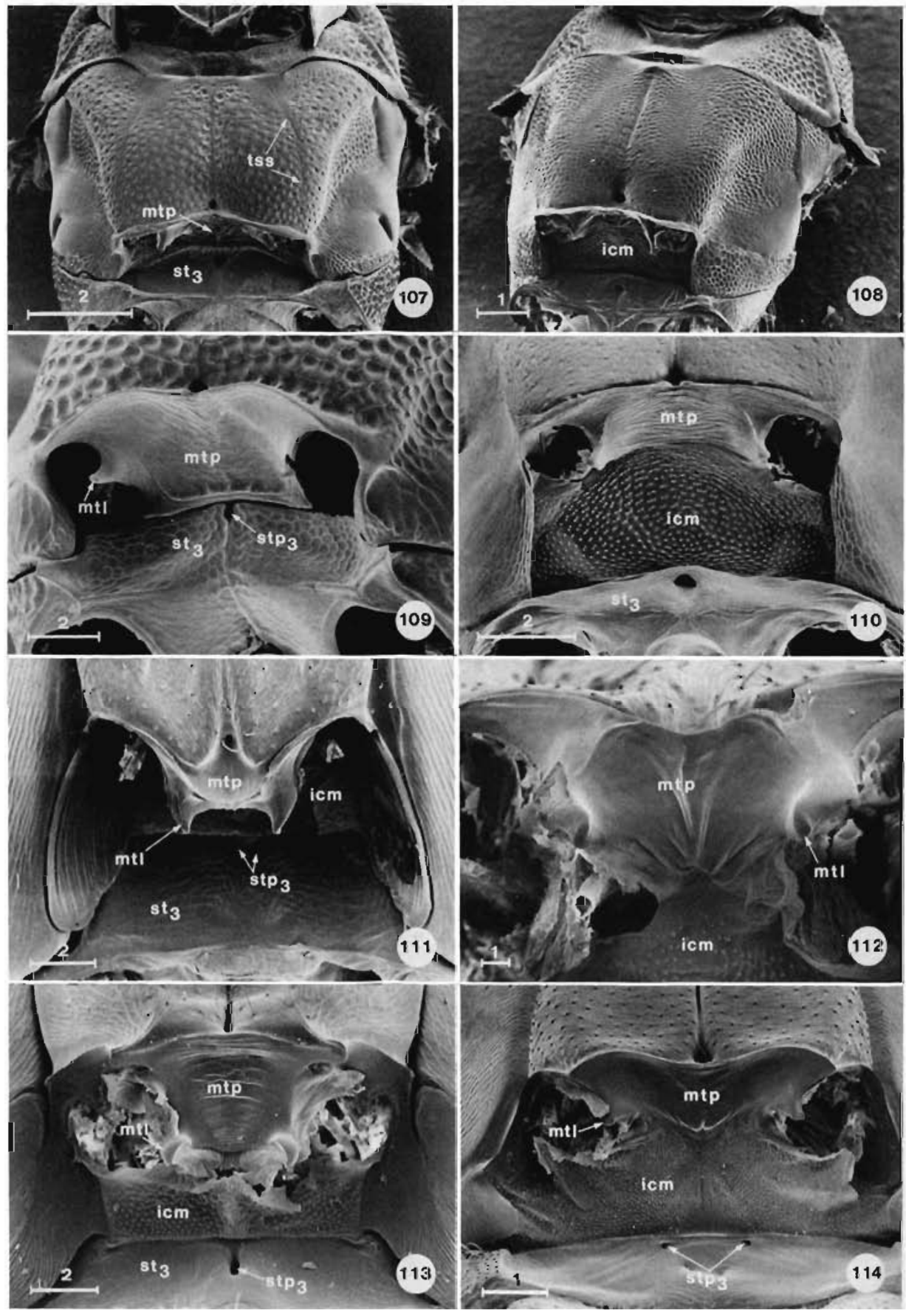

FiGs. 107-114. (Scale bar $=\times 100 \mu \mathrm{m}$.) 107 and 108, ventral mesosoma (coxae removed): 107, Chalcedectus

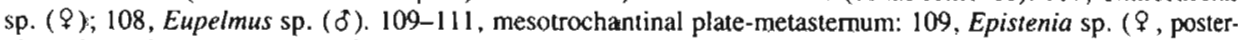
olateral); 110, Brasema sp. (ठ์, posterior); 111, Lambdobregma schwarzii (Ashmead) ( $\$$, ventral). 112, $L$. schwarzii, mesotrochantinal plate $(q$, posterior). 113 and 114 , mesotrochantinal plate-metasternum $(q$, posterior): 113, Neanastatus sp.; 114, Metapelma spectabile Westwood 

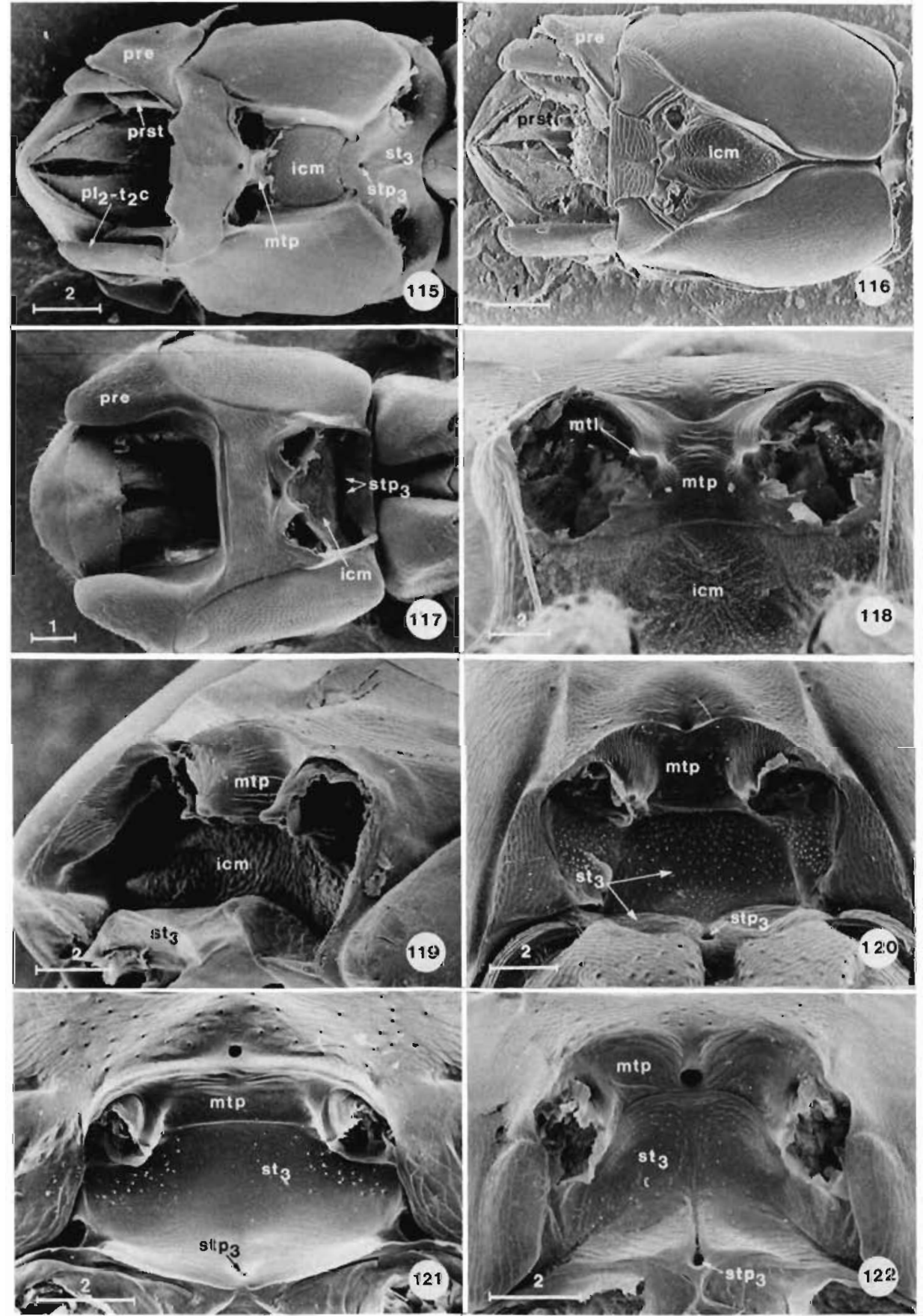

FiGs. 115-122. (Scale bar $=\times 100 \mu \mathrm{m}$.) $115-117$, ventral mesosoma ( 9 , pronotum and coxae removed): 115 , Encyrtus fuscus (Howard) (right lateral prepectus removed); 116, Charitopus sp. (right lateral prepectus and prepectal strut removed); 117, Tanaostigmodes albiclavus Girault. 118, T. albiclavus ( 9 , mesotrochantinal plate, posterior). 119-122, mesotrochantinal plate-metasternum ( 9 ): 119, Cynipencyrius flovus Ishii (posterolateral); 120, Eutrichosomella sp. (posterior); 121, Aphelinidae, genus indet. (posterior); 122, Coccophagus sp. (posterior) 

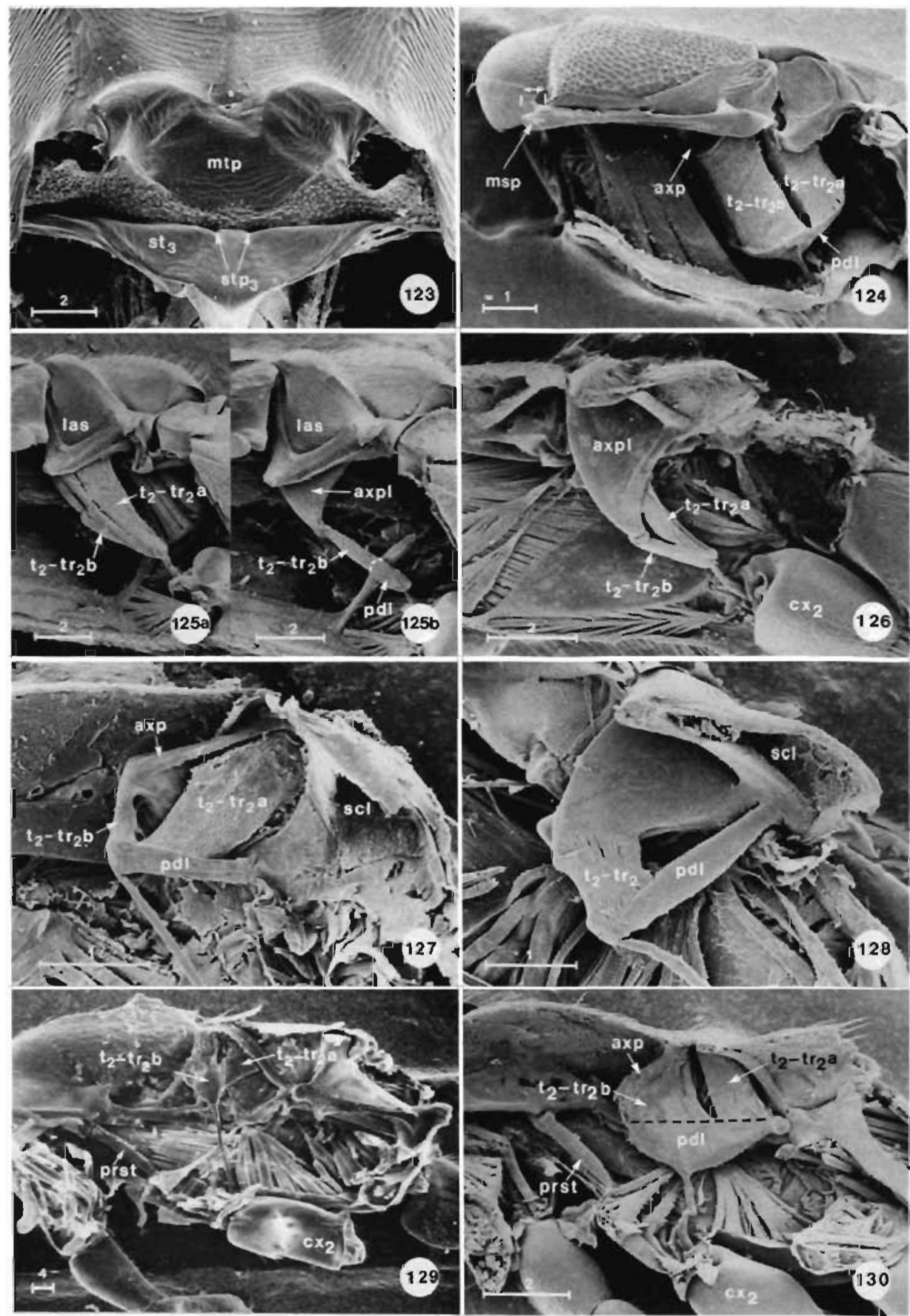

Figs. 123-130. (Scale bar $=\times 100 \mu \mathrm{m}$.) 123, Euryischia sp. ( 8 , mesotrochantinal plate-metastemum, posterior). 124-130, $\mathrm{t}_{2}-\mathrm{tr}_{2}$ muscle ( 9 ): 124, Eusandalum sp. (outer); 125, Metapelma spectabile Westwood (125a, outer, 125b, outer view with $\mathrm{t}_{2}-\mathrm{tr}_{2}$ a removed); 126, M. speciabile (sagittal); 127, Neanastatus sp. (sagittal); I28. Lambdobregma schwarzii (Ashmead) (sagittal); 129, Encyrtidae, genus indet. (sagittal); 130, Encyrtus fuscus (Howard) (sagittal). 

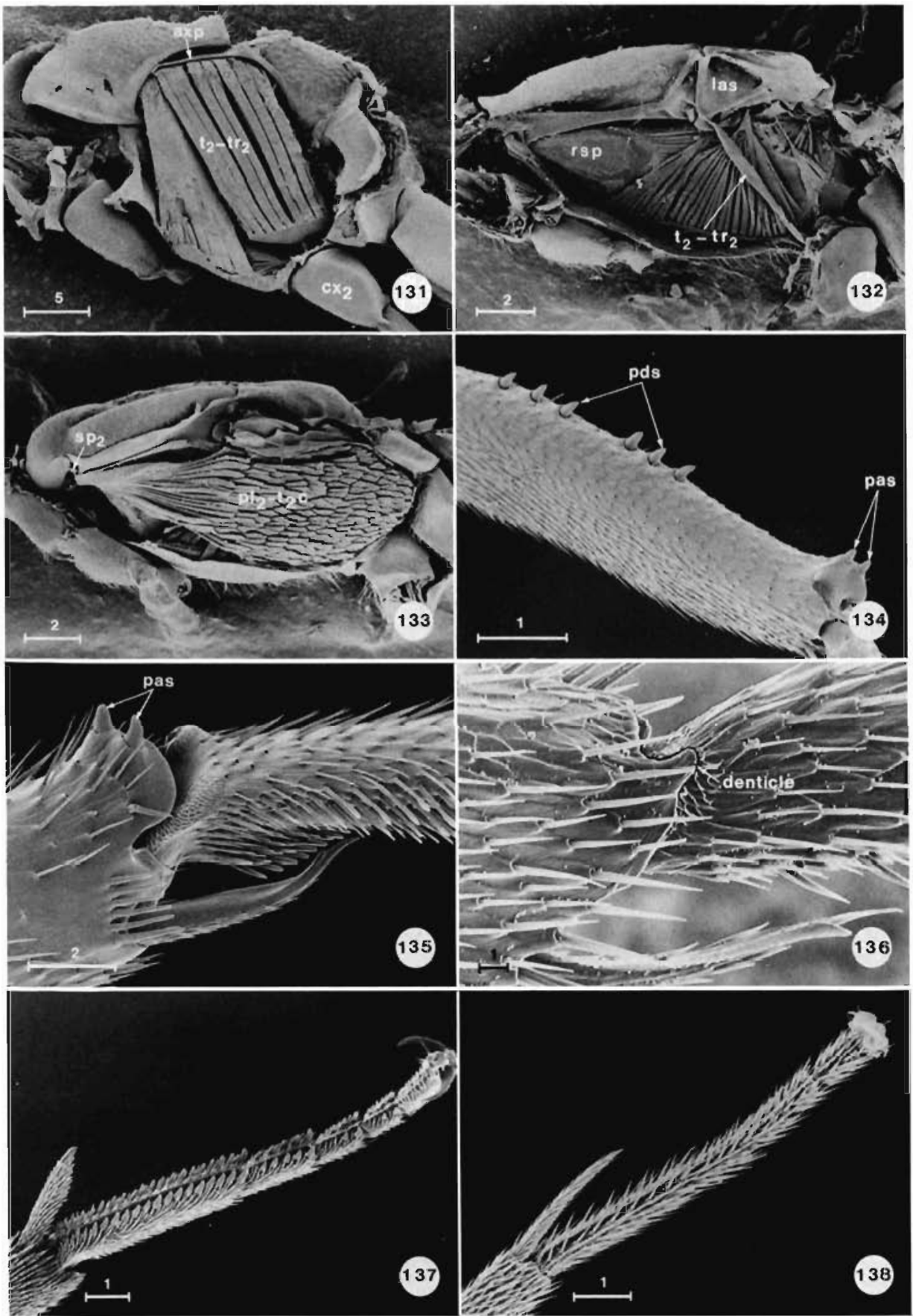

Figs. 131-138. (Scale bar $=\times 100 \mu \mathrm{m}$.) 131 and $132, \mathrm{t}_{2}-\mathrm{tr}_{2}$ muscle $(8$, sagittal): 131 , Epistenia sp.; 132 , Eupelmus sp. 133, Eupelmus sp. ( 9 , lateral mesosoma, prepectus and cuticle of acropleuron removed). 134136, protibia ( 9 ): 134, Eusandalum cyaneum (Ashmead) (dorsolateral); 135, E. cyaneum (apex); 136, Tanaostigmodes howardii Ashmead (apex). 137 and 138, apex of mesotibia, mesotarsus: 137, Oodera sp. (\$); 138, Brasema sp. ( 8 ). 

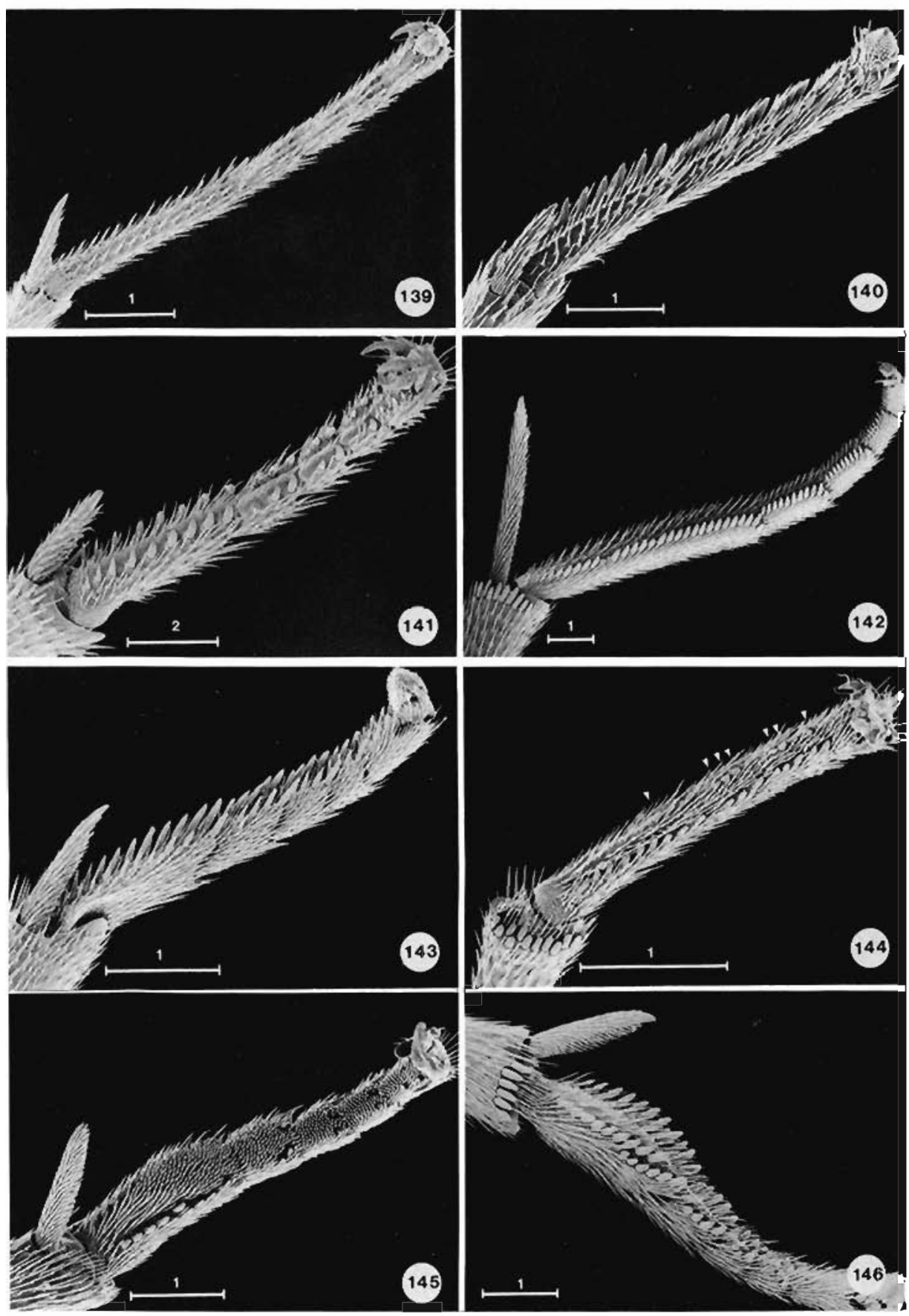

Figs. 139-146. (Scale bar $=\times 100 \mu \mathrm{m}$.) Apex of mesotibia, mesotarsus: 139, Archaeopelma iropeosergum sp.nov. ( $\delta$ ); 140, Eusandalum sp. (8); 141, Licrooides umbilicasus sp.nov. (o); 142, Metapelma specrabile Westwood ( 8 ): 143. Tanaostigmodes albiclavus Girault ( 8 ; 144, Cynipencyrtus favus Ishii (8); 145, Macroneura vesiculuris (Retzius) (Q); 146, Eupelmus sq. ( 9 ). 

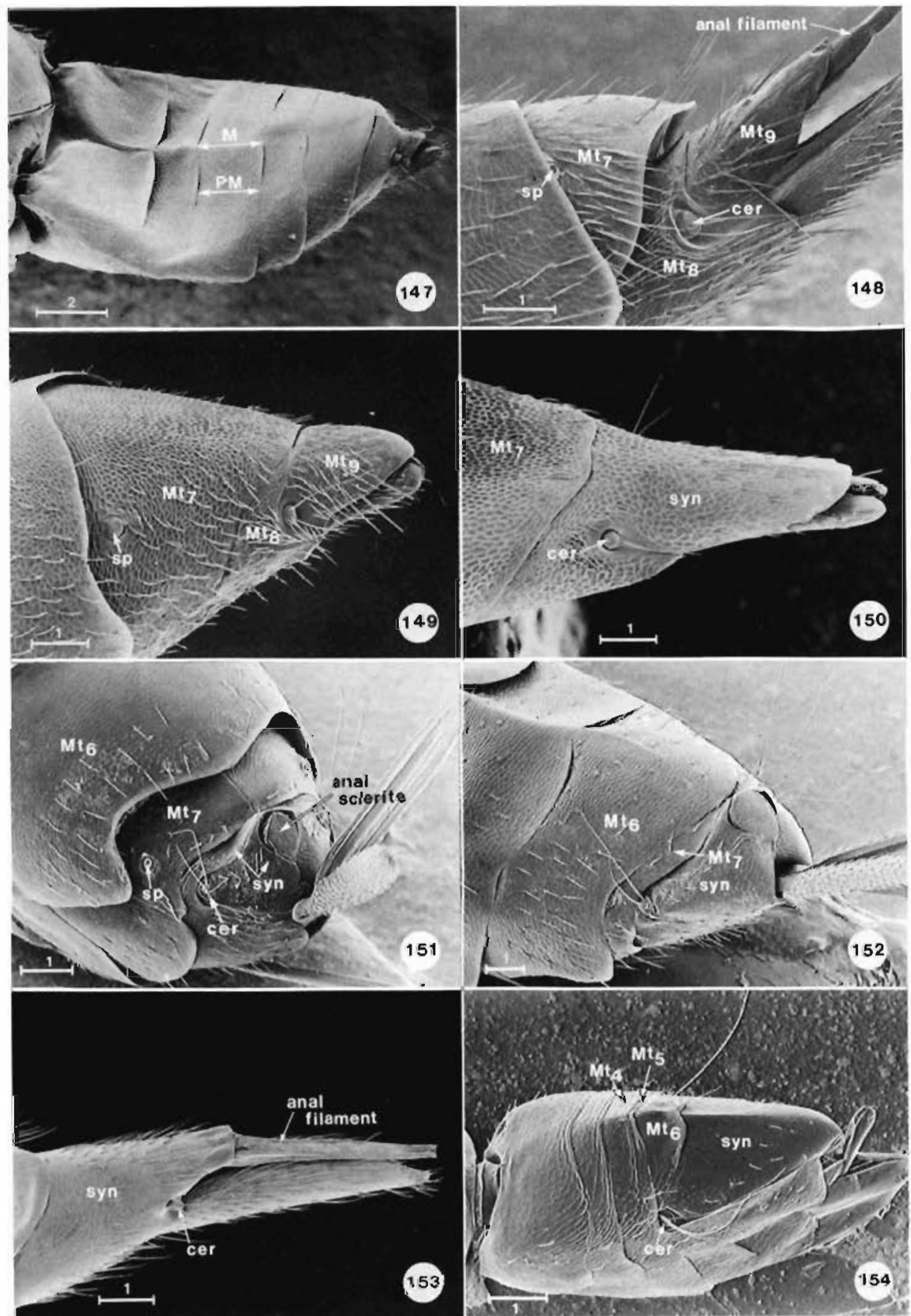

FIGs. 147-154. (Scale bar $=\times 100 \mu \mathrm{m}$.) 147, Tanaostigmodes howardii Ashmead ( $\&$, dorsolateral metasoma) [see "Methods" section for explanation of " $\mathrm{M}$ " and "PM"]. 148-153, dorsolateral apex of metasoma ( $\$$ ): 148, Metapelma spectabile Westwood; 149, Eusandalum sp.; 150, Chirolophus eques Haliday; 151, Eupelmus sp. (Mt 6 distended); 152, Eupelmus sp.; 153, Oodera sp.; 154, Chariropus sp. ( 9 , dorsolateral metasoma). 